\title{
Strong Employers and Weak Employees: How Does Employer Concentration Affect Wages?
}

\author{
by \\ Efraim Benmelech \\ Northwestern University and NBER
}

Nittai K. Bergman
Tel Aviv University

Hyunseob Kim

Cornell University

\section{CES 18-15 April, 2018}

The research program of the Center for Economic Studies (CES) produces a wide range of economic analyses to improve the statistical programs of the U.S. Census Bureau. Many of these analyses take the form of CES research papers. The papers have not undergone the review accorded Census Bureau publications and no endorsement should be inferred. Any opinions and conclusions expressed herein are those of the author(s) and do not necessarily represent the views of the U.S. Census Bureau. All results have been reviewed to ensure that no confidential information is disclosed. Republication in whole or part must be cleared with the authors.

To obtain information about the series, see www.census.gov/ces or contact Christopher Goetz, Editor, Discussion Papers, U.S. Census Bureau, Center for Economic Studies 5K028B, 4600 Silver Hill Road, Washington, DC 20233, CES.Working.Papers@census.gov. To subscribe to the series, please click here. 


\begin{abstract}
We analyze the effect of local-level labor market concentration on wages. Using plant-level U.S. Census data over the period 1977-2009, we find that: (1) local-level employer concentration exhibits substantial cross-sectional and time-series variation and increases over time; (2) consistent with labor market monopsony power, there is a negative relation between local-level employer concentration and wages that is more pronounced at high levels of concentration and increases over time; (3) the negative relation between labor market concentration and wages is stronger when unionization rates are low; (4) the link between productivity growth and wage growth is stronger when labor markets are less concentrated; and (5) exposure to greater import competition from China (the "China Shock") is associated with more concentrated labor markets. These five results emphasize the role of local-level labor market monopsonies in influencing firm wage-setting.
\end{abstract}

\footnotetext{
* We thanks David Autor, Nick Bloom, Roni Michaely, Larry Mishel, Matt Notowidigdo, and Sergio Rebelo for useful comments. We also thank Eric Kim for research assistance, Bert Grider at the TRFSRDC for helping with data and clearance requests, and Evan Buntrock at the NYFSRDC (Cornell) for administrative assistance. Any opinions and conclusions expressed herein are those of the authors and do not necessarily represent the views of the U.S. Census Bureau. All results have been reviewed to ensure that no confidential information is disclosed.
} 


\section{INTRODUCTION}

Wages in the United States have exhibited puzzling behavior in recent decades. Real wage growth has slowed since the early 1970s, particularly at lower values of the wage distribution (Acemoglu and Autor 2011). Although productivity growth has also diminished, the link between productivity growth and increases in real hourly compensation appears to have declined since the early 1980s (see, e.g., Mishel 2012; Bivens and Mishel 2015; and Uguccioni, 2016). Consistent with these trends, the labor share of national income in the United States has diminished, particularly since the early 2000s (e.g., Karabarbounis and Neiman 2014).

Understanding these phenomena has been the focus of much research within economics. The literature has proposed a number of potential - and non-mutually exclusive - explanations for the stagnation in wages and the decline in the labor income share. Among these are increased globalization, with an emphasis on increased trade and competition with China (e.g., Autor, Dorn, and Hanson 2013; and Elsby, Hobijn, and Şahin 2013); changes in technology and the relative cost of capital goods, particularly as stemming from increased industrial automation (see, e.g., Karabarbounis and Neiman 2014; Brynjolfsson and McAfee 2014; and Acemoglu and Restrepo 2016); and an increase in rents flowing to landowners as opposed to labor (Rognlie 2015). Another important avenue of research in understanding the behavior of labor income focuses on secular changes in the industrial composition of firms within the United States, with an emphasis on the increase in product market concentration within the corporate sector in the United States since the late 1990s (see, e.g., Barkai 2016; and Autor et al. 2017).

In the spirit of the literature on market concentration, in this paper we use micro-level data from the U.S. Census Bureau to analyze how monopsony power in local labor markets affects wage behavior. Whereas much prior work on the labor income share focuses on the decrease in competition within the product market - that is, on firms' ability to exploit market power to increase prices and markups, thereby extracting rents (see, e.g., Barkai 2016; Grullon, Larkin, and Michaely 2016; Autor et al. 2017; De Locker and Eeckhout 2017; and Gutiérrez and Philippon 2017) — we focus on concentration within the market for labor: that is, the ability of monopsonist employers in the corporate sector to exploit their market power to reduce wages. Further, because the relevant market associated with job search is largely local-labor mobility in the U.S. has declined significantly and job switches often occur between positions in the same 
area (Moretti 2011; and Molloy, Smith, and Wozniak 2014) - our analysis emphasizes the importance of measuring labor market concentration within relatively localized geographic areas.

Our analysis combines two main sources of data from the U.S. Census Bureau over the sample period 1977-2009. First, to measure local-level labor market concentration, we use the Longitudinal Business Database (LBD) to construct the Herfindahl-Hirschman Index (HHI) of firm employment at the county-industry-year level: HHI is calculated at the local industry level under the plausible assumption that employees' specific human capital and mobility costs constrain their job searches toward firms within the same industry and geographical area. These HHI measures of employer concentration are then related to measures of average wages and productivity at the establishment level constructed from the Census of Manufacturers (CMF) and the Annual Survey of Manufacturers (ASM).

We obtain five main results. First, local-level employer concentration exhibits significant cross-sectional and time series variation. During 1977-2009, the standard deviation of local-level employer HHI (defined at the 4-digit SIC-level) was 0.33, equal to approximately half of the mean local-level HHI of 0.68. Further, the data show that local-level employer concentration has increased considerably over time, with mean county-level HHI calculated at the 4-digit SIC level increasing by approximately 8\%, from an HHI of 0.698 during 1977-1981 to an HHI of 0.756 during 2002-2009.

Our second result establishes our baseline finding: there is a negative relation between the local-level HHI measures of employer concentration and wages. Employers operating in areas with more concentrated labor markets thus appear able to exploit monopsony power in order to reduce employee wages. To mitigate concerns regarding correlations between the local-level HHI measure of concentration and other observable and unobservable differences across plants, industries, and local areas (see, e.g., Boal and Ransom 1997), we show that our results continue to hold after controlling for a host of observables likely to affect wages. These include establishment-level labor productivity, local labor market size, as well as firm-by-year fixed effects. Identification is thus achieved using within firm-year variation, comparing multiple establishments belonging to the same firm but located in areas, or belonging to industries, with varying levels of labor market concentration. The findings are also robust to the use of industry- 
by-year fixed effects together with firm-by-year fixed effects. ${ }^{1}$ This battery of controls removes any common cross-industry variation within firms, thereby alleviating cross-industry heterogeneity as an alternative channel that drives wage differences. We further show that our baseline results continue to hold in a subsample of firms that operate multiple plants in only one industry segment. Using this subsample in conjunction with firm-by-year fixed effects, we largely sidestep cross-industry heterogeneity as an alternative explanation.

The economic magnitude of the baseline negative relation between employer concentration and wages is significant: over the sample period, a one standard deviation increase in the HHI measure of local employer concentration reduces wages by between $1 \%$ and $2 \%$, depending on the specification. Importantly, we show that this baseline relation is highly nonlinear and convex, with labor market concentration at high levels of employer HHI exhibiting a particularly strong effect on wages-plausibly due to reduced worker bargaining power at these levels of concentration. Further, our results indicate that the negative relation between employer concentration and wages approximately doubles in magnitude over the sample period. This strengthening of the sensitivity of wages to employer concentration is consistent with a secular decline in worker bargaining power over time, as would be predicted by the reduction in labor mobility in the United States (constraining the choice-set of workers as they search for employment and negotiate over compensation) or by the drop in unionization rates within the United States beginning in the 1970s (Card 1992).

Our third finding concerns the impact of unionization on the relation between employer concentration and wages. We hypothesize that by improving employee bargaining power, unionization may diminish the ability of employers to lower wages in concentrated labor markets. The data, indeed, bear this out. The negative relation between the HHI labor market concentration measure and wages is significantly weaker amongst plants in industries with high unionization rates. In industries with unionization rates near zero, a one standard deviation increase in local-level employer concentration is associated with a decline in wages between $2.5 \%$ and $5.3 \%$. In contrast, at the average unionization rate, the sensitivity between local level labor market concentration and wages declines by more than a third.

\footnotetext{
${ }^{1}$ We obtain identification of both industry-by-year as well as firm-by-year fixed effects because multi-establishment firms may operate establishments in more than one industry.
} 
Fourth, we investigate how local-level labor market concentration affects the transmission of productivity growth into higher wages. We hypothesize that high levels of employer concentration impede the translation of productivity growth to wage increases, as employers use their monopsony power to avoid wage increases. In contrast, when labor markets are more competitive, productivity increases should give rise to wage growth as employers compete for workers. Put differently, productivity growth should translate into a rise in wages when employee bargaining power is sufficiently high.

Measuring labor productivity at the establishment level using Census data, we first confirm a link between wage growth and productivity growth, measured at an annual frequency (see, e.g., Stansbury and Summers 2017). Importantly, consistent with our hypothesis on the role of monopsony power in labor markets, we find that the link between wage growth and productivity growth is larger when local-level employer concentration is low. Decreasing the employer-based HHI measure of concentration by one standard deviation from its mean of 0.545 is associated with a $9.5 \%$ increase in the elasticity of wages to productivity. ${ }^{2}$

Our fifth result investigates the impact of increased trade with China - the "China Shock"on the level of local labor market concentration. In contrast to our prior findings, in this analysis we focus on the determinants, rather than the effects, of labor market concentration. We hypothesize that by causing employers to shut down a fraction of their operations, increased import competition from China may have led to an increase in local labor market concentration. This is indeed confirmed in the data: a rise in industry-level import penetration from China is associated with increased employer concentration in the local labor market. Aside from labor displacement and an associated decline in wages due to reduced labor demand, increased import competition from China may thus have an additional effect of reducing wages of non-displaced workers due to an increase in employer concentration.

Our paper relates to a growing literature dealing with monopsony in labor markets. ${ }^{3}$ However, most prior empirical work on monopsony power in labor markets and the implied ability of firms to control wages is indirect. Examples include anecdotal evidence on lawsuits against employer collusion using anti-poaching agreements (U.S. Department of Justice Office

\footnotetext{
${ }^{2}$ In related work, Benmelech, Bergman, and Kim (2017) show that the relation between wage growth and productivity growth is increasing in unionization rates. Consistent with the results above, when worker bargaining power rises, increased productivity translates into wage growth.

${ }^{3}$ For reviews, see Boal and Ransom (1997) and Council of Economic Advisers Issue Brief (2016).
} 
of Public Affairs 2014; Whitney 2015) and studies beginning with Card and Krueger (1994) showing that minimum wage increases are not followed by reductions in employmentconsistent with nonperfectly competitive labor markets. Other studies show that the propensity of workers to leave their jobs after wage declines is smaller than would be expected in competitive markets, suggestive of employers' wage-setting ability (Dube, Lester, and Reich 2010, 2016).

In contrast to these studies, we provide a direct measure of the degree of local-level labor market competition and relate it to wage behavior on a host of margins. As such, our article is most closely related to contemporaneous work by Azar, Marinescu, and Steinbaum (2017), which uses online job postings from the website CareerBuilder.com to construct a local-level measure of employer concentration based on commuting zones and occupations. Azar et al.'s chief finding is that increased local-level labor market concentration within a given occupation and commuting zone predicts lower online wage postings. Though related, the two papers are differentiated along a number of important dimensions. We use actual wages (at the establishment level) as taken from the Census Bureau, whereas Azar et al. analyze wage postings offered by firms. Our study uses a series of data that span more than three decades and cover the entire manufacturing sector, whereas Azar et al. examine online wage posting within CareerBuilder.com (that is, not solely focused on manufacturing) over a relatively short time (preceding the 2008-2009 crisis). Further, because our study focuses on manufacturing, we can control directly for productivity - an important covariate when analyzing wages - at the establishment-year level. Last, and most importantly, we provide novel evidence on the timeseries evolution of employer concentration, the impact of unionization on the relation between local employer concentration and wages, how labor market concentration affects the transmission of productivity changes into wage growth, and the effect of the "China Shock" on local employer concentration. Interestingly, we also find that the negative relation between concentration and wages is convex and more pronounced in a setting that approaches textbooklike monopsony - that is, when the local HHI employer concentration measure approaches one. In contrast, Azar et al. show that the negative relation in their setting is not driven by monopsony.

The rest of the article is organized as follows. Section II presents the data and summary statistics. Section III presents the empirical analysis, and Section IV concludes. 


\section{DATA AND KEY VARIABLES}

\section{II.A. Data Sources and Sample Construction}

1. Plant-Level Data. To construct measures of wages and labor productivity we obtain data on manufacturing establishments ("plants") from the Census of Manufacturers (CMF) and the Annual Survey of Manufacturers (ASM) maintained by the U.S. Census Bureau. The CMF covers all manufacturing plants in the United States for years ending in the digits 2 and 7 ("Census years"), resulting in roughly 300,000 plants in each Census. The ASM covers approximately 50,000 plants for non-Census years. The ASM includes all plants with more than a threshold number of employees, with this threshold increasing from 250 to 1,000 during our sample period. ${ }^{4}$ Plants with fewer employees are sampled randomly, with the probability of inclusion increasing in size. Although the ASM is called a survey, reporting is mandatory if the plant is selected, and misreporting is subject to legal penalties and fines. Both databases provide operating information at the plant level, including the total value of shipments, wages, labor hours, and material and energy costs. A key advantage of the CMF and ASM data over standard firm-level databases of public firms such as Compustat is that they comprise both privately and publicly owned plants, covering a significant fraction of U.S. workers.

We also use the Longitudinal Business Database (LBD) to construct measures of concentration of firms' employment within a county-industry. The LBD is a comprehensive data set of manufacturing and nonmanufacturing establishments in the United States, tracking more than 5 million establishments per year. The database provides plant-level number of employees, annual payroll, industry classification, and geographic location (i.e., counties and states). We use the LBD rather than the ASM and CMF data to construct measures of labor market concentration since the LBD tracks nearly the entire population of establishments at a yearly frequency. In contrast, the ASM tracks a varying subset of plants over time (due to sampling issues explained above) while the CMF is constructed only at a five-year frequency.

In our analysis we also use a set of common control variables standard among research analyzing plant-level data using the CMF and ASM datasets (see, e.g., Schoar 2002). Specifically, firm size is measured by the log number of plants of a given firm, while firm segment size, defined at the firm-industry level, is measured by the log number of plants belonging to the firm in a given industry. Plant age is defined as the number of years since a

\footnotetext{
${ }^{4}$ The thresholds are 250 employees before 1999, 500 from 1999 to 2003, and 1,000 after 2003.
} 
plant's inception - identified by the flag for plant inception in the LBD — or its first appearance in the CMF or ASM database, whichever is the earliest. The starting year is censored in 1972 when the coverage of the Census databases begins.

We require each plant observation to have variables necessary to estimate average wages and labor productivity, including total value of shipments, production-worker equivalent hours, total wages, and number of employees (both production and nonproduction). ${ }^{5}$ Because our identification strategy relies on within-firm variation in wages and employer concentration across plants, we require that firm-years have at least two plants under their ownership. In addition, we require that each plant-year have a one-year lagged observation, which is needed to compute changes in average wages and productivity in part of our analysis. Our selection procedure yields approximately 656,000 plant-years over the sample period $1977-2009 .^{6}$

2. Measuring Employer Concentration, Wages, and Labor Productivity. As our main measure of local employer concentration we use the Herfindahl-Hirschman Index (HHI) of firm employment at the county-industry-year level. Using the LBD data we first measure the employment share of every firm in a given county-industry-year cell as: $s_{f, j, c, t}=\frac{e m p_{f, j, c, t}}{\sum_{f=1}^{N} e m p_{f, j, c, t}}$, where $e m p_{f, j, c, t}$ represents total employment of firm $f$ in industry $j$ in county $c$ in year $t$. We calculate the locallevel HHI as the sum of the squared employment shares at the country-industry-year level: $H H I_{j, c, t}=\sum_{f=1}^{N} s_{f, j, c, t}^{2}$. We construct two variants of the employer-concentration HHI measures using either three- or four-digit SIC codes to define industries.

We use the log of average wages per worker at the plant-year level as our main dependent variable. Average wages at the plant-year level are calculated as the total wage bill at the establishment divided by its number of workers. We also use labor productivity (per hour) as a control variable, defined as output divided by total labor hours. As is standard, output is computed as the sum of the total value of shipments and the net increase in inventories of finished goods and works in progress. To account for industry-level changes in output price, we divide output by the four-digit SIC-level output price deflator from the NBER-CES manufacturing industry database constructed by Bartelsman, Becker, and Gray (2000). Total

\footnotetext{
${ }^{5}$ The ASM and CMF databases provide SIC codes until 2002 and NAICS codes thereafter. We impute SIC codes after 2002 .

${ }^{6}$ The numbers of observations are rounded to the nearest thousand to follow the Census Bureau's disclosure rules.
} 
labor hours is measured by "production-worker equivalent hours" computed using the ASM and CMF data (as in Lichtenberg 1992; Kovenock and Phillips 1997). Specifically, total labor hours are constructed as the total production-worker hours multiplied by total wages divided by wages for production workers.

3. Union Coverage Data. We obtain data on collective bargaining coverage from the Union Membership and Coverage Database constructed and administered by Hirsch and Macpherson (2003). ${ }^{7}$ This database provides estimates for the fraction of private- and public-sector workers covered by labor unions. Prior research on financial and labor economics uses the database to estimate industry-level collective bargaining coverage (e.g., Matsa 2010; and Elsby, Hobijn, and Şahin 2013). Below we provide a detailed account of the data source and construction that are relevant for our empirical analysis.

Hirsch and Macpherson (2003) compute the fraction of workers covered by labor unions at the industry-level using the monthly household Current Population Survey (CPS). In particular, they follow the methodology employed by the Bureau of Labor Statistics (BLS) to calculate estimates of the percentage of employees who are covered by labor unions at the national level, defined as the number of employees covered by labor unions divided by total employment. In addition, the Union Membership and Coverage Database provides union coverage rate estimates by Census Industry Code (CIC) beginning in 1983 (national-level coverage rate estimates are available from 1977). Because our plant-level data utilize SIC codes, we match the union coverage data with Census plant-level data at the industry level as follows. ${ }^{8}$ For the years 1983-2002, we use the Census Bureau's concordances between the 1980 and 1990 CIC codes and SIC codes. For 2003-2009, during which the CIC is based on NAICS codes, we first match the $2000 \mathrm{CIC}$ to $1990 \mathrm{CIC}$ codes using the Census Bureau's crosswalk and then use the Census Bureau's concordance between 1990 CIC and SIC codes to match with the Census plant-level data. ${ }^{9}$

\footnotetext{
${ }^{7}$ The database is available at www.unionstats.com.

${ }^{8}$ Hirsch and Macpherson (2003) use the 1980 CIC classification (based on SIC codes) from 1983 to 1991, the 1990 CIC from 1992 to 2002 (based on SIC codes), and the 2000 CIC (based on NAICS codes) from 2003 and on.

${ }^{9}$ For the majority of CIC industries used in the CPS, this matching procedure results in direct linkages to three-digit SIC industries. In a minority of cases, the procedure results in a match to a two- or four-digit SIC industry, in which case the coarser industry classification is used.
} 
Our analysis focuses on manufacturing plant-year observations in the ASM and CMF databases from 1977 to 2009 (the first and last years of data coverage). Given that our industrylevel database on union coverage begins in 1983 while our sample period starts in 1977, we impute the rate of collective bargaining coverage using 1983 information for years between 1977 and 1982.

\section{II.B. Descriptive Statistics}

Table I reports descriptive statistics for the characteristics of the plant observations over the period 1977-2009. The average plant in the sample has \$96 million in total value of shipments ("sales"), 349 employees, and an average wage of $\$ 41,840$ per year. ${ }^{10}$ The average plant-level log labor productivity is 4.61 , while average plant age is 17.1 years. Firms in our sample own on average 32 plants, while the average firm segment has ten plants. The average union coverage rate for the manufacturing plants in our sample is $22.8 \%$

Focusing on our measures of local-level employer concentration - the mean employer concentration HHI measure defined at the three-digit SIC level is 0.545 , while the mean fourdigit SIC-based HHI measure is 0.682 . The standard deviation of employer concentration is substantial, exceeding 60 percent of the mean for the three-digit HHI concentration measure and approximately equal to half the mean for the four-digit HHI concentration measure.

Figure I plots trends in local-level employer concentration over the sample period 19772009, showing that employer concentration increased considerably. During 1977-1981, the average local-level HHI concentration measure (defined at the four-digit SIC level) was 0.698, increasing by 8.3 percent to an average of 0.756 during 2002-2009. ${ }^{11}$ This upward trend in local employer HHI is consistent with increasing concentration in local labor markets in the U.S. over the past decades.

In our analysis below we also define indicator variables that take the value of one in county-industries in which the employer concentration HHI measure equals one, and zero otherwise. These HHI-based indicator variables are designed to capture counties with high monopsony power of one large employer within a given industry. As Table I shows, such high

\footnotetext{
${ }^{10}$ Due to the Census Bureau's disclosure rules, we do not report variable percentiles.

${ }^{11}$ Average employer concentration measures in Figure I are calculated at the industry-county level using industrycounty-level employment as weights. Summary statistics in Table I do not weigh plant observations by employment.
} 
degree of concentration is not uncommon, with $22.7 \%$ of plant-year observations in counties in which there is only one employer in a given three-digit SIC industry.

\section{EMPIRICAL ANALYSIS}

\section{III.A. Relation between Employer Concentration and Wages}

We begin by investigating a reduced-form baseline relation between employer concentration and wages. To this end, we run the following regression:

$$
\log (\text { avg. wages })_{p f j t}=\beta_{0}+\beta_{1} H H I_{j c t-1}+\beta_{2} \boldsymbol{X}_{p f j t}+\beta_{3} Z_{j c t-1}+\boldsymbol{\delta}_{j t}+\boldsymbol{\mu}_{f t}+\boldsymbol{\varepsilon}_{p f j}
$$

where $\log (\text { avg. wages })_{p f j t}$ is $\log$ average wages per worker in plant $p$, owned by firm $f$, operating within industry $j$, in year $t$. $H H I_{j c t-1}$ is the one-year lagged employment-based measure of concentration in county $c$ and industry $j$, defined at either the three- or four-digit SIC level; $\boldsymbol{X}_{p f j t}$ is a vector of plant-level control variables comprising the log of labor productivity, the log of the number of plants per segment within the firm, the log of the number of plants per firm, and plant age; $\boldsymbol{Z}_{j c t-1}$ is the one-year lagged log of aggregate employment at the county-industry level; $\boldsymbol{\delta}_{j t}$ is a vector of either industry or industry-by-year fixed effects and $\boldsymbol{\mu}_{f t}$ is a vector of firm or firm-byyear fixed effects. All standard errors are clustered at the county level.

Panel A of Table II provides the results from estimating regression (1) using three-digit SIC codes to compute the HHI employment concentration measure. As column (1) of Table II shows, the coefficient estimate for $\log$ (employment) is 0.042 and statistically significant at the $1 \%$ level, suggesting that wages are higher in local labor markets with more workers. This finding is consistent with economic forces related to agglomeration (e.g., Ellison, Glaeser, and Kerr 2010; and Greenstone, Hornbeck, and Moretti 2010). As would be expected, the coefficient on log labor productivity is positive (equal to 0.156 and significant at the $1 \%$ level), indicating a positive relation between productivity and wages.

Turning to our main variable of interest and still focusing on column 1 of Table II, which includes year fixed effects in addition to log employment at the three-digit industry-county level and plant-level labor productivity as controls, the results indicate a negative coefficient on the local-level HHI measurer of concentration. Thus, consistent with the hypothesis that labor market monopsony power detrimentally affects wages, the data show that wages are negatively related to the degree of employer concentration in the local labor market. This relation is 
statistically significant at the $1 \%$ level, and the economic magnitude is sizable - a one standard deviation increase in employer concentration $(0.35)$ is associated with a $0.88 \%$ decrease $(=0.35$ $\times-0.025)$ in average wages. Similarly, the relation between $\log$ average wages and employer concentration is statistically and economically significant when other plant-level controls are added such as firm, firm-segment size, and plant age (column (2)) and industry fixed effects are included (column (3)). The plant-level explanatory variables - in particular, log(labor productivity) and plant age — control for plant-level productivity, alleviating the concern that our results are driven by productivity differences across plants. Further, by including industry fixed effects, we exploit within-industry variation of employer concentration to identify the relation between wages and employer concentration. Thus, the estimates in column (3) are based off of variation in employer concentration across different local labor markets within a given industry.

Columns 4 and 5 of Table II include firm and firm-by-year fixed effects, respectively. The latter specification exploits within firm-year variation by comparing, within a given year, plants owned by the same firm that are located in counties and industries with varying levels of employer concentration. With the inclusion of firm-by-year fixed effects in column (5), the semielasticity of wages to employer concentration is -0.023 . Thus, increasing the employer concentration HHI measure by the sample standard deviation of 0.35 decreases wages by $0.8 \%$. Wages thus appear to be negatively correlated with employer concentration, consistent with the prediction that concentration of employers in the local labor market gives firms monopsony power which can be used to reduce wages.

While the analyses in columns (4) and (5) mitigate the concern that lower wages in more concentrated labor markets are due to heterogeneity across firms, a remaining concern is that the negative association between local employer concentration and wages is driven by omitted differences across different industries within firms in a given year. For example, a firm may have a more productive industry segment (e.g., machinery) in a less concentrated local labor market, and a less productive segment (e.g., chemicals) in a more concentrated market, which may lead to a spurious correlation between concentration and wages due to differences in productivity levels.

To address this concern, in column (6) of Table II we also include, in addition to firm-byyear fixed effects, a vector of industry-by-year fixed effects which absorb time-varying industrylevel shocks. In this analysis the identifying variation stems from plants operating in the same 
industry and belonging to the same firm located in different counties with varying levels of employer concentration. Including industry-by-year fixed effects, column (6) shows that the semi-elasticity of wages to employer concentration is -0.049 , which is more than twice the effect without controlling for time-varying industry shocks in column (5). This result suggests that once we compare plants in the same industry and firm, those located in a more concentrated local labor market pay lower wages, with a standard deviation increase in employer concentration associated with a $1.7 \%$ decline in wages. Panel B of Table II repeats the analysis in Panel A using four-digit SIC industries to compute the HHI measure of employer concentration. The negative relation between concentration and employee wages is evident in this panel as well. The economic magnitude of the effect is larger than that in Panel A, with a semi-elasticity ranging from -0.038 to -0.063 relative to -0.023 to -0.049 in Panel A.

To further alleviate the concern that industry-level heterogeneity (in productivity in particular) is driving the relation between employer concentration and wages, we focus our estimation on a subsample of firms that operate multiple plants within a single industry segment (defined at either the three- or four-digit SIC level). Combined with firm-by-year fixed effects, use of this subsample removes cross-industry variation within firms, thereby sidestepping crossindustry heterogeneity as an alternative channel that drives wage differences.

Table III presents the results from estimating equation (1) using a subsample of firms that operate multiple plants within one industry segment, defined at the three- (Panel A) or four-digit SIC level (Panel B). As Table III illustrates, across all columns the coefficient on the employer concentration HHI measure is negative and significant at the $1 \%$ level, consistent with the baseline result in Table II. The economic magnitude is approximately double that exhibited in Table II (e.g., -0.061 and -0.023 in column (5), which includes firm-by-year fixed effects), indicating that the effect is larger amongst the subset of firms that are unlikely to be affected by cross-industry heterogeneity in productivity and wages. Panel B, which uses four-digit SIC codes to define employer concentration, shows a qualitatively similar result, with economic magnitudes again larger than those in Panel B of Table II. In sum, our results are robust to the inclusion of industry-by-year fixed effects and hold in multi-plant, single-industry firms, thus alleviating concerns that industry-level heterogeneity is driving the negative relation between employer concentration and wages. 


\section{III.B. Subsample Periods}

We next investigate how the relation between wages and employer concentration evolves over the sample period. To this end, Table IV divides the full sample from 1977 to 2009 into five-year subperiods and reruns the wage regressions in regression (1), which include the HHI measure of employer concentration as the key independent variable. ${ }^{12}$ As shown in Panel A of Table IV, the coefficient on the HHI measure of employer concentration - defined at the threedigit SIC level-increases over time, implying an increasing sensitivity of wages to local labor market concentration over the sample period. In the first two subsamples, 1977-1981 and 19821986, the coefficients on HHI are -0.018 and -0.012 , respectively. This coefficient increases to -0.031 in $1992-1996,-0.039$ in 1997-2001, and in the final subsample, the coefficient is -0.029. In Panel B, which uses four-digit SIC industries to compute employer concentration, the increasing pattern is muted, although the effect of concentration on wages is the greatest between 1992 and 2001 ( -0.044 to -0.047$)$.

One potential explanation for the increasing sensitivity between wages and employer concentration over time is the decline in labor mobility over the sample period across both economic sectors and geographical areas (see, e.g., Murphy and Topel 1987; and Molloy, Smith, and Wozniak 2014). The effect of local labor market monopsony hinges on limits to labor mobility across markets (for a review, see Boal and Ransom 1997). Thus, to the extent that workers have become less mobile in the United States over past decades, employer concentration at the local level is more likely to restrict workers' employment choice-set, explaining a rising sensitivity between wages and employer concentration over the sample period. An additional mechanism potentially explaining the rise in the sensitivity of wages to employer concentration is the secular decline in employee bargaining power stemming from the decline in unionization rates beginning in the 1970s (see e.g., Card 1992). It is to this mechanism, which we turn to next.

\section{III.C. Employer Concentration, Unions, and Wages}

While employer concentration may enable firms to pay lower wages, unionization strengthens labor's bargaining position and may enable employees to diminish employers' monopsony power. We next empirically test whether unionization mitigates the ability of firms to reduce wages in concentrated markets. To do so, we interact our local measure of employer

\footnotetext{
${ }^{12}$ The five-year subperiods in Table IV match those employed in Figure I. The final subperiod is 2002-2009.
} 
concentration (HHI) with the degree of unionization at the industry level, employing the following regression specification:

$$
\begin{aligned}
\log (\text { avg. wages })_{p f j t}= & \beta_{0}+\beta_{1} H H I_{j c t-1}+\beta_{2} H H I_{j c t-1} \times \text { Union }_{j t-1}+\beta_{3} \text { Union }_{j t-1}+\beta_{4} \boldsymbol{X}_{p f j t}+\beta_{5} \boldsymbol{Z}_{j c t l} \\
& +\boldsymbol{\delta}_{j t}+\boldsymbol{\mu}_{f t}+\boldsymbol{\varepsilon}_{p f j t}
\end{aligned}
$$

where Union $_{j-1}$ is the one-year lagged union coverage rate for industry $j$ associated with plant $i$, and all other variables as defined in regression (1). The main coefficient of interest in this regression is $\beta_{2}$, which measures the degree to which unionization rates affect the sensitivity of wages to employer concentration.

Table V presents estimates of regression (2) using plant-level data from 1977 to $2009 .{ }^{13}$ Columns (1) and (2) in Panel A show that, as in Table II, controlling for year fixed effects, and employing plant-level and county-industry-level controls, average workers' wages at manufacturing plants are lower when the local labor market (defined at the county level) is more concentrated in a given three-digit SIC industry. Importantly, the coefficient on the interaction term between local employer concentration and the unionization coverage rate is positive. Consistent with the hypothesis, the negative relation between employer concentration and wages is thus mitigated amongst plants that operate in industries with higher unionization rates. For example, focusing on column (2) of Table V, in industries at the average rate of union coverage $(22.8 \%)$ a one standard deviation increase in the employer concentration HHI measure reduces wages by approximately $2.1 \%$. In contrast, in industries with near-zero unionization rates, the same increase in employer concentration is associated with an approximately $5.3 \%$ decline in wages. $^{14}$

Columns (3)-(5) further include industry, firm, and firm-by-year fixed effects and exhibit results consistent with those in columns (1) and (2) - the negative effect of employer concentration is mitigated by high unionization rates at the industry level. In terms of economic magnitude, estimates in column (5) indicate that a one standard deviation increase in

\footnotetext{
${ }^{13}$ As explained in Section II.A, data on industry-level union coverage rates are available from 1983 only. Thus, we impute unionization coverage rates before 1983 (i.e., 1977-1982) using values for corresponding industries in 1983.

${ }^{14}$ Alternatively, the regression estimates in column (2) suggest that a one standard deviation increase in unionization rates $(12.9 \%)$ from their average $(22.8 \%)$ reduces the semi-elasticity of wages to employer concentration by an order of magnitude, from -0.061 to -0.009 .
} 
unionization rates from their average reduces the semi-elasticity of wages to HHI substantially, from -0.035 to -0.005 .

Column (6) includes firm-by-year fixed effects as well as industry-by-year fixed effects to control for time-varying industry shocks, finding consistent evidence that greater unionization rates mitigates the negative association between employer concentration and wages. Based on the coefficients in this column, a one standard deviation increase in employer concentration reduces wages by $2.8 \%$ in industries with a zero unionization rate, while reducing wages by $1.7 \%$ at the mean rate of industry unionization. The results are thus consistent with unions providing bargaining power to workers in wage negotiations, mitigating a negative effect of local labor market concentration on wages.

In Panel B of Table V we repeat the analysis in Panel A using four-digit SIC industries to compute local-level HHI employer concentration. The results reported in Panel B are consistent with those found in Panel A, with labor unions reducing the sensitivity of wages to employer concentration.

\section{III.D. Employer Concentration and Rent Sharing}

The analysis thus far has focused on the relation between employer concentration and wages in local labor markets. In addition to wage levels, concentration of employers may also affect the transmission of productivity growth into wage changes. Standard economic theory would suggest that in competitive, or near-competitive labor markets, increases in labor productivity should translate into increased wages, with workers paid their marginal product. Empirical evidence has provided general support for a link between productivity and wage growth (see e.g. Stansbury and Summers 2017), although this link appears to have declined since the early 1980s (see e.g., Mishel 2012 and Bivens and Mishel 2015). Following these results, we

hypothesize that labor market employer concentration impedes the translation of productivity growth to wage increases, as employers use their monopsony power to avoid wage hikes, thereby capturing rents from increased productivity. To empirically test whether the sensitivity of wage growth to productivity growth is affected by local-level employer concentration, we use the following first-differences interaction specification: 
$\Delta \log (\text { avg. production worker wages })_{p f j t}=\beta_{0}+\beta_{1} H H I_{j c t-1}+\beta_{2} \Delta \log (\text { labor productivity })_{p f j t}$

$+\beta_{3} H H I_{j c t-1} \times \Delta \log (\text { (labor productivity })_{p f j t}+\beta_{4} \boldsymbol{X}_{p f j t}+\beta_{5} \boldsymbol{Z}_{j c t l}+\boldsymbol{\delta}_{j t}+\boldsymbol{\mu}_{f t}+\boldsymbol{\varepsilon}_{p f j t}$,

where $\Delta \log$ (avg. production worker wages $)_{p f j t}$ is the log change in average plant wages for production workers and $\Delta \log ($ labor productivity) pfit is the log change in labor productivity in plant $p$, industry $j$, county $c$, and year $t$. All control variables are defined as in regression (1) while $\boldsymbol{\delta}_{j t}$ is a vector of industry fixed effects and $\boldsymbol{\mu}_{f t}$ is a vector of firm fixed effects. We focus on production workers in this specification since their compensation is potentially more sensitive to productivity due to rent sharing (e.g., Freeman and Medoff 1981).

Table VI reports estimation results. Across columns in Panel A of Table VI, the coefficient on $\Delta \log$ (labor productivity) is positive and significant at the $1 \%$ level, confirming a positive association between wage growth and productivity growth at the plant level (see, e.g., Stansbury and Summers 2017). Importantly, consistent with our prediction regarding the role of monopsony power in labor markets, the coefficient on the interaction term $H H I \times \Delta \log$ (labor productivity) is negative and significant at the $1 \%$ level. Estimates in column (5) imply that a one standard deviation decrease in HHI from its mean increases the elasticity of production worker wages to productivity by $9.5 \%$, from $0.127(=0.146-0.035 \times 0.545)$ to $0.139(=0.146-0.035$ $\times(0.545-0.350))$. Alternatively, moving from an HHI employer concentration measure of zero to an HHI concentration measure equal to one (representing 22.7 percent of the sample), reduces the elasticity of wages to productivity by approximately $25 \%$, from 0.146 to 0.111 . Thus, consistent with our prediction, when labor markets are more competitive, productivity increases are associated with larger increases in wages, as employers compete for workers. In contrast, higher levels of employer concentration impede the translation of productivity growth into wage growth.

\section{III.E. Robustness Tests}

1. Nonlinear Effect of Employer Concentration on Wages. Regressions (1) and (2) assume a linear relation between employer concentration, measured by local-level HHI, and average wages. We hypothesize that this relation may exhibit non-linearities, whereby the ability of firms to utilize monopsony power in labor markets to reduce wages is concentrated at particularly high

levels of employer concentration. Table I shows that there is indeed a significant fraction of 
manufacturing plants that are located in counties with extreme concentration: $22.7 \%$ of plantyear observations have an HHI concentration measure equal to one when employer concentration is calculated at the industry-county level using 3-digit SIC codes. While such observations clearly do not correspond to cases of classic monopsony in which a single firm provides employment to workers, these counties arguably correspond to scenarios of particularly high employer concentration.

To formally examine the question of whether the relation between wages and employer concentration is strengthened at high levels of concentration, we include in our standard regression specification an indicator variable that equals one for county-industries with only one firm. We thus run the following regression:

$$
\begin{aligned}
\log (\text { avg. wages })_{p f j t}= & \beta_{0}+\beta_{1} H H I_{j c t-1}+\beta_{2} H H I_{j c t-1} \times \text { Union }_{j t-1}+\beta_{3} \text { Union }_{j t-1}+\beta_{4} D(H H I=1)_{j c t-1}+ \\
& \beta_{5} 1(H H I=1)_{j c t-1} \times \text { Union }_{j t-1}+\beta_{\mathbf{6}} \boldsymbol{X}_{p f j t}+\beta_{7} \boldsymbol{Z}_{j c t 1}+\boldsymbol{\mu}_{f t}+\boldsymbol{\varepsilon}_{p f j t}
\end{aligned}
$$

where $D(H H I=1)_{j c t-1}$ is an indicator variable equal to one if the HHI of industry $j$ in county $c$ in year $t-1$ is equal to one, and zero otherwise, and all other variables are defined as in regression (1). Given that we include firm-by-year fixed effects $\left(\boldsymbol{\mu}_{f t}\right)$, the interpretation of the coefficient on $\beta_{4}$ is the effect of monopsony power of one large employer within a given industry on wages within firms, and across different local labor markets, in a given year.

Table VII reports estimation results. Column (1) includes the HHI = 1 indicator variable but excludes the baseline continuous variable for $\mathrm{HHI}$, as well as the interaction terms with unionization rates. The coefficient on the indicator variable is -0.017 , suggesting that plants in highly concentrated labor markets, as proxied by an HHI equal to one, pay $1.7 \%$ lower wages, controlling for plant- and county-industry-level determinants of wages. Column (2) includes the continuous variable HHI, in addition to the indicator variable, and shows that employer concentration has a negative effect on wages $(-0.011)$ when HHI equals one, over and above the linear effect of HHI $(-0.013)$. The results thus suggest that the negative effect of employer concentration on wages is more pronounced when the local labor market is highly concentrated.

Next, in column (3), we exclude the continuous variable HHI but interact the indicator for HHI equals to one with industry-level unionization rates. Consistent with previous estimates in Table V, we find a positive coefficient on the interaction term: unionized labor significantly 
reduces the relation between wages and local market monopsony. At the average rate of unionization in the sample $(22.8 \%)$, plants in local labor markets with the HHI concentration measure equal to one have wages that are $2.5 \%$ lower $(=-0.062+0.162 \times 0.228)$ than plants owned by the same firm but operating in counties with lower concentration measures. However, a one standard deviation increase in unionization rates reduces the semi-elasticity of wages to employer concentration to a mere $-0.4 \%$, i.e., an $84 \%$ reduction in absolute magnitude from the average effect.

In Panel B, we compute employer concentration using four-digit SIC industries and find results that are consistent with those in Panel A-plants in local labor markets with an HHI concentration measure of one pay wages that are $3.1 \%$ lower than plants owned by the same firm but operating in counties with lower levels of labor market concentration (column (1)). Moreover, estimates in column (2) suggest that the bulk of the effect of employer concentration on wages is, at the margin, around highly concentrated labor markets: the continuous HHI concentration measure is not statistically significant, while the coefficient associated with the $\mathrm{HHI}=1$ indicator variable is -0.029 and significant at the $1 \%$ level. Column (3) in Panel B presents results similar to those in Panel A: at the average rate of unionization in the sample, plants in county-industries with an HHI employer concentration measure of one pay wages that are $3.5 \%$ lower $(=-0.058+0.101 \times 0.228)$ than plants owned by the same firm but operating in counties with lower concentration measures. Further, a one standard deviation increase in unionization rates reduces the wage to employer concentration semi-elasticity to $-2.2 \%$, a $37 \%$ reduction from the average effect. Overall, results in Table VII suggest that the effect of employer concentration in local labor markets is more pronounced amongst counties exhibiting particularly high levels of employer concentration.

2. Controlling for National-Level Employer Concentration. Autor et al. (2017) show that product markets in the United States have become more concentrated in the past few decades, giving rise to "superstar firms" that are highly productive yet have lower labor shares of income. Related to these findings, one concern regarding our results is that if product market concentration - commonly defined at the national level for traded sectors such as manufacturing - and local labor market concentrations are positively correlated, then the negative association 
between local employment concentration and wages may merely reflect a negative relation between (national) product market concentration and labor shares.

We note first that as part of our identification strategy we include firm-by-year fixed effects. As such, we exploit within firm-year variation across plants belonging to the same firm. This speaks against the hypothesis that our results are driven by heterogeneity across firms, as for example implied by "superstar firms". To further alleviate this concern, we control for the effect of product market competition by constructing our employer HHI concentration measures at the national level. We first measure the employment share of every firm in a given industryyear cell as: $s_{f, j, t}=\frac{e m p_{f, j, t}}{\sum_{f=1}^{N} e m p_{f, j, t}}$, where $e m p_{f, j, t}$ represents total employment in firm $f$ operating in industry $j$ in year $t$. We next calculate the industry-year HHI as the sum of the squared employment shares: $H H I_{j, t}=\sum_{f=1}^{N} s_{f, j, t}^{2}$. As with the local-level HHI, we define two variants of the national-level HHI using either three- or four-digit SIC codes. We then include the nationallevel HHI as a control for product market concentration in regression (1).

Table VIII, Panel A, shows that the coefficient on national-level HHI (calculated using 3digit SIC codes) is significantly positive in all but one specification in which it is statistically insignificant, inconsistent with the alternative explanation that high levels of product market concentration are associated with lower wages. Importantly, even with the inclusion of the national HHI measure of employer concentration, the coefficient on the local HHI remains negative and the magnitudes sizable, with, for example, a semi-elasticity of wages to local-level concentration of -0.043 (column (5) of the table). Panel B, which uses the four-digit SIC level as the definition of industry, shows a consistent result that the coefficient on local-level HHI does not change much when national-level HHI is added as a control.

3. Controlling for Labor Value Added. One concern regarding the negative relation between employer concentration and wages presented in our baseline results is that the local-level HHI measure is correlated with labor productivity, implying that the results may be capturing the effect of low productivity, rather than employer concentration, on wages. Although all regressions control for the log of labor productivity (defined as the natural log of output scaled by labor hours), this variable may still be an imperfect control for actual labor productivity. To alleviate this concern, in Table IX we add an additional control variable for labor productivitynamely, value added (VA) by labor - to the regression specification. As is standard, value added 
is defined as the total value of shipments plus the net increase in inventories of finished goods and works in progress minus material and energy costs scaled by total labor hours, with all components deflated using four-digit SIC industry-level deflators (available from the NBERCES manufacturing database). One key difference of labor value added relative to our labor productivity measure is that the former nets out intermediate inputs (i.e., material and energy), which are presumably not affected by labor inputs.

Table IX, Panel A shows that in most specifications the coefficient on $\log ($ labor VA) is positive and significant at the $1 \%$ level, consistent with the notion that employees of plants who add more value per labor hour are paid more. Importantly, however, the coefficients on the HHI measure of employer concentration remain statistically significant and their magnitudes are almost identical to those found in Table II, suggesting that the baseline relation between HHI and wages is unlikely to be driven by omitted controls for value added by workers or labor productivity. Panel B, which uses four-digit SIC codes to define employer concentration, exhibits similar results with the coefficient on local employment concentration largely unaffected by the addition of value added by labor.

\section{III.F. Wages, Market Concentration, and the China Shock}

There is a growing body of literature that investigates the impact of increased trade with Chinathe "China Shock" - on labor markets in the United States. For example, Autor, Dorn, and Hanson (2013) and Autor et al. (2014) find that local labor markets more exposed to import penetration from China exhibit higher unemployment, lower labor-force participation, and reduced wages. In this subsection, we add to the literature on the "China Shock" and the labor market effects of increased globalization by investigating the effect of import penetration from China on local labor market concentration. We hypothesize that by causing employers to shut down a fraction of their operations, increased import competition from China may have led to an increase in local labor market concentration. Thus, we argue that in addition to labor displacement and an associated decline in wages due to reduced labor demand, increased import competition from China may have an additional effect of reducing wages of non-displaced workers due to an increase in employer concentration.

We construct an industry-by-year measure of import penetration from China to the United States equal to the industry-level dollar value of imports scaled by the total value of 
shipments in the industry in a given year. ${ }^{15}$ Specifically, we define import penetration from


the dollar value of imports from China to the United States, Shipmentsi,j,t represents the total value of shipments, and $i$ represents a plant that operates in industry $j$ and year $t$. We limit our analysis to plant-years from 1992 through 2008, given that the China import penetration data are available from 1991 to 2007 and that we use lagged China exposure as an independent variable.

We first adjust our main empirical specification in regression (1) by including China Exposure as an additional control. Table X, Panel A presents the results and shows that the coefficient on China Exposure measured at the three-digit SIC level is negative and significant at the $1 \%$ level, consistent with existing research documenting negative consequences of the China shock on labor market outcomes. The economic magnitude of the effect is sizable as well-a one standard deviation increase in China exposure is associated with a $0.95 \%(=-0.001 \times 9.508)$ reduction in average wages. Importantly, however, including this direct control for the China exposure does not significantly affect our estimates for HHI-the coefficient on HHI remains negative and significant at the $1 \%$ level. Panel $\mathrm{B}$, which uses four-digit SIC codes shows a similar result - controlling for the China shock does not alter the baseline relation between employer concentration and wages.

We next turn to analyzing the effect of the China shock on labor market concentration. Given the disruptions to the manufacturing sector documented in Autor et al. (2013, 2014), we hypothesize that increased exposure to competition from China should increase local-level employer concentration. As such, we are interested herein in a determinant of labor market concentration, in contrast to the results in prior sections dealing with the effects of such concentration.

To analyze how the China shock relates to employer concentration, we run the following specification, regressing the local-level HHI employer concentration measure on our measure of exposure to competition from China:

$$
H H I_{j c t}=\beta_{0}+\beta_{1} \text { China Exposure } e_{t}+\beta_{2} \boldsymbol{X}_{p j j t}+\beta_{3} \boldsymbol{Z}_{j c t-1}+\boldsymbol{\delta}_{j t}+\boldsymbol{\mu}_{f t}+\boldsymbol{\varepsilon}_{p f j t} .
$$

\footnotetext{
${ }^{15}$ The data sources for the import and total value of shipment data are U.N. Comtrade and the ASM and CMF, respectively. We thank David Dorn for making the import data available on his website.
} 
$H H I_{j c t}$ is local-level employer concentration in county $c$ and industry $j$ measured at either the three- or four-digit SIC level; China Exposure $j$ is defined as the total value of imports from China to the United States scaled by the total value of shipments for industry $j$ in year $t$; and all other variables defined as in regression (1).

Table XI presents the results for estimating regression (5) using three-digit SIC industries. We find that the coefficient on exposure to Chinese imports is significantly positive at the $1 \%$ level, suggesting that industry-level import competition is indeed associated with increased concentration of employers in the local labor market. In terms of economic magnitude, estimates in column (4), which includes firm-by-year fixed effects, suggest that a one standard deviation increase in Chinese import competition leads to a $0.018(=0.002 \times 9.508)$ increase in HHI, which is sizable relative to the mean HHI of 0.544 . We obtain similar results when we define industries based on the four-digit SIC level. ${ }^{16}$

After confirming our hypothesis that increased import competition from China is associated with higher local employer concentration, it is natural to hypothesize that such exposure to Chinese imports will have an indirect effect on wages, through increased local-level labor market concentration. According to this, increased exposure to import competition from China increases employer concentration, thereby reducing wages. However, given that exposure to China affects wages directly (as shown in Autor et al. 2013, 2014), using import penetration from China as an instrument for employer concentration does not meet the exclusion restriction. Hence, it is empirically challenging to disentangle the indirect effect from the direct effect of exposure to Chinese import competition on wages.

\section{CONCLUSION}

We use manufacturing plant-level data from the U.S. Census Bureau from 1977 to 2009 to provide evidence that wages are significantly lower in local labor markets in which employers are more concentrated. The negative relation between employer concentration and wages increases over time and is particularly strong in labor markets with high levels of employer concentration. Our results also show that the sensitivity of wages to employer concentration is reduced when labor unionization rates rise. Thus, in the presence of concentrated labor markets, unionization may mitigate monopsony power in labor markets by increasing workers' bargaining

\footnotetext{
${ }^{16}$ We omit these results for brevity.
} 
positions in wage determination processes. In addition, we show how higher employer concentration impairs the transmission of productivity growth into wage increases. As such, the results suggest that weak bargaining power reduces the ability of workers to benefit from productivity growth. Finally, we analyze one particular determinant of local labor market concentration, showing that increased exposure to competition from China led to higher concentration of employers. 


\section{REFERENCES}

Acemoglu, Daron, and David H. Autor, "Skills, Tasks and Technologies: Implications for Employment and Earnings," in Handbook of Labor Economics, vol. 4B, David Card and Orley Ashenfelter, eds. (Amsterdam: Elsevier, 2011), 1043-1171.

Acemoglu, Daron, and Pascual Restrepo, "The Race between Machine and Man: Implications of Technology for Growth, Factor Shares and Employment,” NBER Working Paper 22252, 2016.

Autor, David H., David Dorn, and Gordon H. Hanson, "The China Syndrome: Local labor Market Effects of Import Competition in the United States," American Economic Review, 103 (2013), 2121-2168.

Autor, David H., David Dorn, Gordon H. Hanson, and Jae Song, "Trade Adjustment: WorkerLevel Evidence," Quarterly Journal of Economics, 129 (2014), 1799-1860.

Autor, David, David Dorn, Lawrence F. Katz, Christina Patterson, and John Van Reenen, "The Fall of the Labor Share and the Rise of Superstar Firms," Working Paper, 2017.

Azar, Jose, Ioana Marinescu, and Marshall I. Steinbaum, "Labor Market Concentration," NBER Working Paper 24147, 2017.

Barkai, Simcha, "Declining Labor and Capital Shares," Stigler Center for the Study of the Economy and the State, New Working Paper Series, 2016.

Bartelsman, Eric, Randy Becker, and Wayne Gray, "NBER-CES Manufacturing Industry Database," National Bureau of Economic Research, 2000.

Benmelech, Efraim, Nittai Bergman, and Hyunseob Kim, "Why Did Rent-Sharing Vanish in the United States?," Working Paper, 2017.

Bivens, Josh, and Lawrence Mishel, "Understanding the Historic Divergence between Productivity and a Typical Worker's Pay,” EPI Briefing Papers 406, 2015.

Boal, William M., and Michael R. Ransom, 1997, "Monopsony in the Labor Market," Journal of Economic Literature, 35 (1997), 86-112.

Brynjolfsson, Erik, and Andrew McAfee, The Second Machine Age: Work, Progress, and Prosperity in a Time of Brilliant Technologies (New York: W. W. Norton, 2014).

Card, David, "The Effect of Unions on the Distribution of Wages: Redistribution or Relabelling?," NBER Working Paper 4195, 1992. 
Card, David, and Alan B. Krueger, "Minimum Wages and Employment: A Case Study of the Fast-Food Industry in New Jersey and Pennsylvania," American Economic Review, 84 (1994), 772-793.

Council of Economic Advisers Issue Brief, "Labor Market Monopsony: Trends, Consequences, and Policy Responses," 2016.

De Locker, Jan, and Jan Eeckhout, "The Rise of Market Power and the Macroeconomic Implications," Princeton University, working paper, 2017.

Dube, Arindrajit, William T. Lester, and Michael Reich, "Minimum Wage Effects across State Borders: Estimates Using Contiguous Counties," Review of Economics and Statistics, 92 (2010), 945-964.

—, "Minimum Wage Shocks, Employment Flows and Labor Market Frictions," Journal of Labor Economics, 34 (2016), 663-704.

Ellison, Glenn, Edward L. Glaeser, and William R. Kerr, "What Causes Industry Agglomeration? Evidence from Coagglomeration Patterns," American Economic Review, 100 (2010), 1195-1213.

Elsby, Michael W. L., Bart Hobijn, and Ayşegül Şahin, “The Decline of the U.S. Labor Share,” Brookings Papers on Economic Activity (2013), 1-52.

Gutiérrez, Germán, and Thomas Philippon, "Investment-less Growth: An Empirical Investigation," Working Paper, 2017.

Greenstone, Michael, Richard Hornbeck, and Enrico Moretti, "Identifying Agglomeration Spillovers: Evidence from Winners and Losers of Large Plant Openings," Journal of Political Economy, 118 (2010), 536-598.

Grullon, Gustavo, Yelena Larkin, and Roni Michaely, “Are US Industries Becoming More Concentrated?," Working Paper, 2016.

Hirsch, Barry T., and David A. Macpherson, "Union Membership and Coverage Database from the Current Population Survey: Note," Industrial and Labor Relations Review, 56 (2003), $349-354$.

Karabarbounis, Loukas, and Brent Neiman, “The Global Decline of the Labor Share," Quarterly Journal of Economics, 129 (2014), 61-103. 
Kovenock, Dan, and Gordon Phillips, "Capital Structure and Product Market Behavior: An Examination of Plant Exit and Investment Decisions," Review of Financial Studies, 10 (1997), 767-803.

Lichtenberg, Frank, Corporate Takeovers and Productivity (Cambridge, MA: MIT Press, 1992).

Matsa, David, "Capital Structure as a Strategic Variable: Evidence from Collective Bargaining," Journal of Finance, 65 (2010), 1197-1232.

Mishel, Lawrence, "The Wedges between Productivity and Median Compensation Growth," Issue Brief, Economic Policy Institute, 2012.

Molloy, Raven, Christopher L. Smith, and Abigail Wozniak, "Declining Migration within the U.S.: The Role of the Labor Market,” NBER Working Paper 20065, 2014.

Moretti, Enrico, 2011, “Local Labor Markets,” in Handbook of Labor Economics, vol. 4B, David Card and Orley Ashenfelter, eds. (Amsterdam: Elsevier, 2011), 1237-1313.

Murphy, Kevin M., and Robert H. Topel, "The Evolution of Unemployment in the United States: 1968-1985," NBER Macroeconomic Annual (1987), 11-57.

Nickell, Stephen J., and Sushil Wadhwani, “Insider Forces and Wage Determination,” Economic Journal, 100 (1990), 496-509.

Rognlie, Matthew, "Deciphering the Fall and Rise in the Net Capital Share: Accumulation or Scarcity?," Brookings Papers on Economic Activity, Spring 2015.

Schoar, Antoinette, "Effects of Corporate Diversification on Productivity," Journal of Finance, 57 (2002), 2379-2403.

Stansbury, Anna, and Lawrence Summers, "Productivity and Pay: Is the Link Broken?," Working Paper, 2017.

Uguccioni, James, "Decomposing the Productivity-Wage Nexus in Selected OECD Countries, 1986-2013," CSLS Research Report, 2016.

U.S. Department of Justice Office of Public Affairs, "Justice Department Requires eBay to End Anticompetitive 'No Poach"” Hiring Agreements," 2014.

Whitney, Lance, "Apple, Google, Others Settle Antipoaching Lawsuit for \$415 Million," CNET.com, September 3, 2015. 


\section{Figure I: Trends in Average Local-Level Employment Concentration, 1977-2009}

This figure plots trends in the employment-weighted average of the Herfindahl-Hirschman Index (HHI) of employment by firms computed at the county-three-digit industry-year level. The computed HHI is averaged across county-four-digit industry-year cells within each of the five-year periods (the last period includes eight years, 20022009) using the number of employees in each cell as the weight. Thus, the average HHI represents the degree of employer concentration the average worker faces in the labor market.

$$
\begin{aligned}
& 0.760 \\
& 0.750 \\
& 0.740 \\
& 0.730 \\
& 0.720 \\
& 0.710 \\
& 0.700 \\
& 0.690 \\
& 0.680 \\
& 0.670 \\
& 0.660
\end{aligned}
$$


$$
\begin{array}{llllll}
1977-1981 & 1982-1986 & 1987-1991 & 1992-1996 & 1997-2001 & 2002-2009
\end{array}
$$




\section{Table I: Summary Statistics on Plant Observations from the CMF and ASM Sample}

This table presents descriptive statistics on the manufacturing plant-year observations used in the analysis from the CMF and ASM databases for the period 1977-2009. We require each observation in the sample to have all variables necessary to compute labor productivity (and lagged value) and value added per worker (and lagged value). "Total value of shipments" is TVS in the CMF and ASM databases and a measure of sales from plants in million dollars; "Total wage" is the sum of wages for production and nonproduction workers in million dollars; "Total employees" is the number of total employees; "Total labor hours" is the production worker equivalent man hours in thousands; "HHI (SIC3 or 4-county-year)" is the Herfindahl-Hirschman Index (HHI) of employment by firms at the countyindustry (three- or four-digit)-year level; "HHI (SIC3 or 4-county-year) $=1$ " is an indicator variable equal to one if $\mathrm{HHI}=1$, and zero otherwise; "HHI (SIC3 or 4- year)" is the Herfindahl-Hirschman Index (HHI) of employment by firms at the industry (three- or four-digit)-year level; "log(employment, SIC3 or 4-county-year)" is the log number of employees at the county-industry (three- or four-digit)-year level; "Labor productivity" is defined as output divided by total labor hours (a quantity-based measure of labor productivity); "Average wage" is computed as total wage divided by total employees (in thousand dollars); "Average wage, production" is computed as production employee wage divided by total production employees (in thousand dollars); "log(employment, SIC3 or 4-countyyear)" is the log number of employment at the county-industry (three- or four-digit)-year level; "Plants per segment" is the number of plants in a given three-digit SIC industry segment of a given firm; "Plants per firm" is the total number of plants of a given firm; "Plant age" is the number of years since a plant's birth, which is proxied either by the flag for plant birth in the Longitudinal Business Database (LBD) or by its first appearance in the CMF or ASM database, whichever is earliest; and "Unionization rate" is the percentage of the workforce covered by collective bargaining collected by Hirsch and Macpherson (2003). The number of observations is rounded to the nearest thousand to follow the Census Bureau's disclosure rules.

\begin{tabular}{lrr}
\hline \hline & \multicolumn{1}{c}{ Mean } & \multicolumn{1}{c}{ STD } \\
\hline Total value of shipment $(\$ \mathrm{~m})$ & 95.95 & 379.45 \\
Total wage (\$m) & 16.51 & 50.63 \\
Total employees & 348.56 & 816.68 \\
Total labor hours (000) & 817.25 & 3955.94 \\
HHI (SIC3-county-year) & 0.545 & 0.350 \\
HHI (SIC4-county-year) & 0.682 & 0.334 \\
HHI (SIC3-county-year) $=1$ & 0.227 & 0.419 \\
HHI (SIC4-county-year) $=1$ & 0.379 & 0.485 \\
HHI (SIC3-year) & 0.022 & 0.029 \\
HHI (SIC4-year) & 0.044 & 0.048 \\
Log labor productivity & 4.61 & 0.94 \\
Average wage (\$000) & 41.84 & 14.24 \\
Log average wage (\$000) & 3.67 & 0.35 \\
Average wage (\$000), production & 37.61 & 14.33 \\
log(employment, SIC3-county-year) & 6.24 & 1.68 \\
log(employment, SIC4-county-year) & 5.66 & 1.76 \\
Plants per segment (SIC3) & 9.85 & 15.20 \\
Plants per firm & 31.89 & 39.14 \\
Plant age & 17.09 & 8.99 \\
Unionization rate & 0.228 & 0.129 \\
Observations (plant-years) & 656,000 & - \\
\hline \hline
\end{tabular}


Table II: Local Employer Concentration and Wages

This table examines the basic effects of employer concentration in a local labor market on the wages of plants. The dependent variable is the log of average wages per worker as defined in Table I. "HHI" and "log(employment)" are lagged by one year. Panels A and B present estimates using three- and four-digit SIC industries to compute HHI, $\log ($ employment), and $\log$ (plant per segment). The $t$-statistics based on standard errors adjusted for sample clustering at the county level are reported below the coefficient estimates. The numbers of observations are rounded to the nearest thousand to follow the Census Bureau's disclosure rules.

Panel A: 3-digit SIC Industries

\begin{tabular}{|c|c|c|c|c|c|c|}
\hline & (1) & (2) & (3) & (4) & (5) & (6) \\
\hline Dep. Var. & \multicolumn{6}{|c|}{ Log avg. wages } \\
\hline \multirow[t]{2}{*}{ HHI (SIC3-county-year) } & -0.025 & -0.044 & -0.037 & -0.028 & -0.023 & -0.049 \\
\hline & -2.87 & -5.41 & -5.29 & -5.64 & -4.31 & -9.41 \\
\hline \multirow[t]{2}{*}{$\log ($ employment, SIC3-county-year) } & 0.042 & 0.039 & 0.036 & 0.026 & 0.027 & 0.026 \\
\hline & 19.08 & 17.16 & 21.62 & 26.99 & 26.74 & 27.28 \\
\hline \multirow[t]{2}{*}{$\log ($ labor productivity) } & 0.156 & 0.155 & 0.102 & 0.095 & 0.094 & 0.065 \\
\hline & 47.19 & 46.31 & 55.77 & 49.09 & 44.94 & 36.78 \\
\hline \multirow[t]{2}{*}{$\log ($ plant per segment $)$} & - & -0.042 & -0.015 & -0.017 & -0.020 & -0.008 \\
\hline & - & -19.20 & -10.68 & -11.26 & -11.42 & -5.08 \\
\hline \multirow[t]{2}{*}{$\log ($ plant per firm) } & - & 0.041 & 0.021 & -0.016 & - & - \\
\hline & - & 26.63 & 19.28 & -8.96 & - & - \\
\hline \multirow[t]{2}{*}{ Plant age $(/ 100)$} & - & 0.422 & 0.425 & 0.405 & 0.412 & 0.358 \\
\hline & - & 17.61 & 24.27 & 23.23 & 23.31 & 21.94 \\
\hline Year fixed effects & $\mathrm{Y}$ & $\mathrm{Y}$ & $\mathrm{Y}$ & $\mathrm{Y}$ & & \\
\hline Industry fixed effects & & & $\mathrm{Y}$ & & & \\
\hline Industry-year fixed effects & & & & & & $\mathrm{Y}$ \\
\hline Firm fixed effects & & & & $\mathrm{Y}$ & & \\
\hline Firm-year fixed effects & & & & & $\mathrm{Y}$ & $\mathrm{Y}$ \\
\hline Observations & 656,000 & 656,000 & 656,000 & 656,000 & 656,000 & 656,000 \\
\hline $\mathrm{R}^{2}$ & $20.45 \%$ & $22.56 \%$ & $43.90 \%$ & $54.99 \%$ & $62.55 \%$ & $67.18 \%$ \\
\hline
\end{tabular}


Panel B: 4-digit SIC Industries

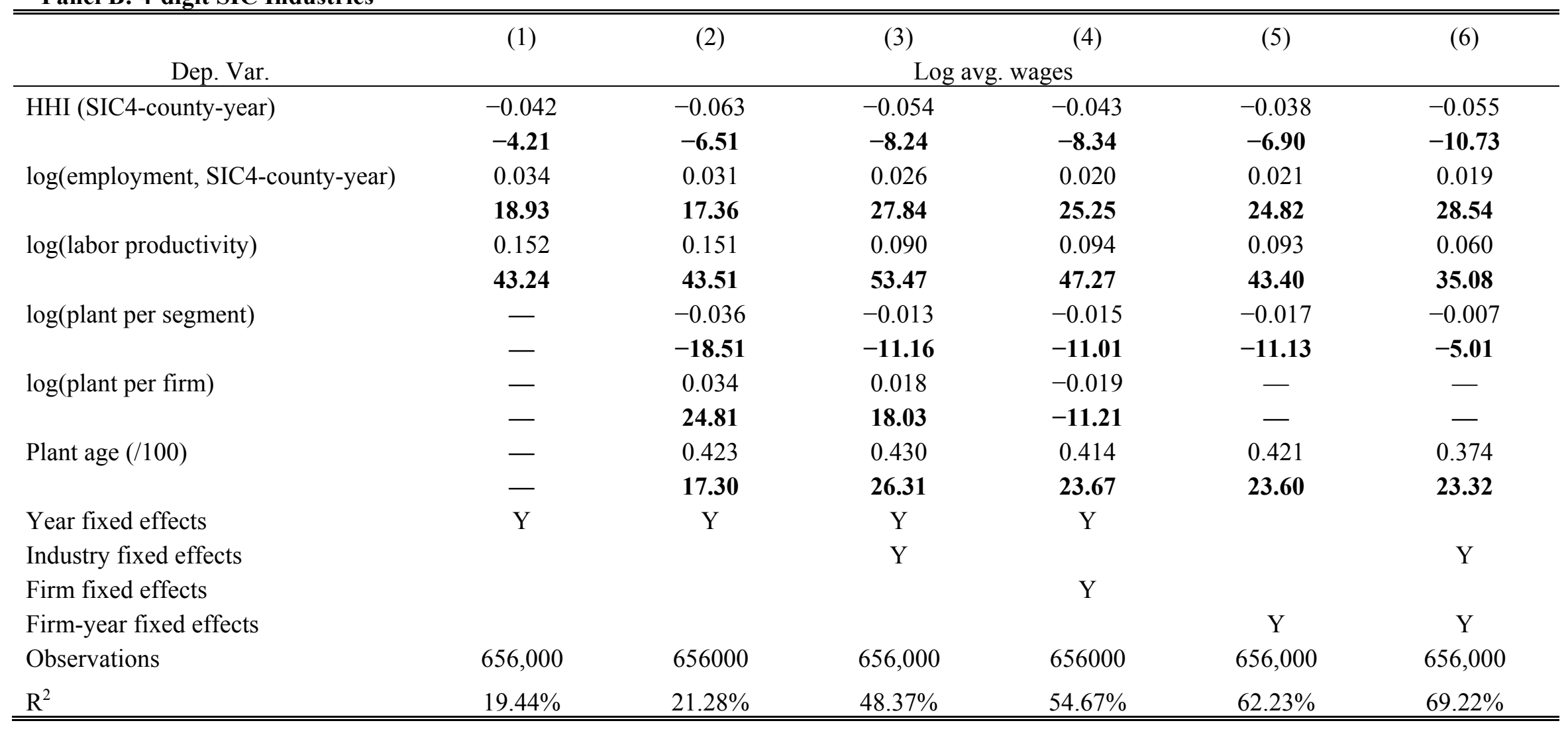




\section{Table III: Subsample of Firms with One Industry Segment across Multiple Plants}

This table examines the effects of employer concentration in a local labor market on the wages of plants using a subsample of plants owned by firms that have multiple plants in only one industry segment. The dependent variable is the log of average wages per worker as defined in Table I. "HHI" and "log(employment)" are lagged by one year. Panels A and B present estimates using three- and four-digit SIC industries to compute HHI, log(employment), and $\log$ (plant per segment). The $t$-statistics based on standard errors adjusted for sample clustering at the county level are reported below the coefficient estimates. The numbers of observations are rounded to the nearest thousand to follow the Census Bureau's disclosure rules.

\section{Panel A: 3-digit SIC Industries}

Dep. Var.

HHI (SIC3-county-year)

$\log ($ employment, SIC3-county-year)

$\log ($ labor productivity)

$\log ($ plant per firm)

Plant age (/100)

Year fixed effects

Industry fixed effects

Industry-year fixed effects

Firm fixed effects

Firm-year fixed effects

Observations

$\mathrm{R}^{2}$
(1)
(2)

(2)

$\begin{array}{cc}-0.065 & -0.080 \\ -\mathbf{5 . 2 9} & -\mathbf{6 . 5 8} \\ 0.034 & 0.032 \\ \mathbf{1 4 . 8 1} & \mathbf{1 3 . 8 1} \\ 0.147 & 0.142 \\ \mathbf{3 7 . 0 6} & \mathbf{3 5 . 7 4} \\ - & 0.031 \\ - & \mathbf{1 4 . 1 3} \\ - & 0.288 \\ - & \mathbf{7 . 1 9} \\ \mathrm{Y} & \mathrm{Y}\end{array}$

(100000

110,000

110,000

110,000

$18.77 \%$
(3) Log avg. wages

-0.071
-6.90

0.025

12.79

0.110

32.87

0.022

12.49

0.327

10.18

Y

$\mathrm{Y}$

(4)

-0.058
-7.14

$-7.14$

0.019

13.88

0.094

30.28

$-0.014$

$\mathbf{- 3 . 9 1}$

0.333

9.26

Y

Y

\begin{tabular}{l}
110,000 \\
$38.09 \%$ \\
\hline
\end{tabular}

(5)

(6)

\begin{tabular}{c}
-0.070 \\
$-\mathbf{6 . 5 9}$ \\
0.018 \\
$\mathbf{1 0 . 7 0}$ \\
0.076 \\
$\mathbf{1 6 . 8 3}$ \\
- \\
- \\
0.335 \\
$\mathbf{7 . 0 4}$ \\
\\
$Y$ \\
$Y$ \\
110,000 \\
$77.58 \%$ \\
\hline
\end{tabular}


Panel B: 4-digit SIC Industries

\begin{tabular}{|c|c|c|c|c|c|c|}
\hline & (1) & (2) & (3) & (4) & $(5)$ & $(6)$ \\
\hline Dep. Var. & \multicolumn{6}{|c|}{ Log avg. wages } \\
\hline \multirow[t]{2}{*}{ HHI (SIC4-county-year) } & -0.080 & -0.096 & -0.078 & -0.069 & -0.071 & -0.078 \\
\hline & $-\mathbf{5 . 7 0}$ & -6.82 & -8.39 & -8.03 & -6.74 & -8.07 \\
\hline \multirow[t]{2}{*}{$\log ($ employment, SIC4-county-year) } & 0.026 & 0.024 & 0.019 & 0.014 & 0.014 & 0.013 \\
\hline & 15.30 & 14.02 & 17.17 & 13.44 & 10.75 & 11.27 \\
\hline \multirow[t]{2}{*}{$\log$ (labor productivity) } & 0.140 & 0.135 & 0.103 & 0.092 & 0.093 & 0.074 \\
\hline & 33.28 & 32.16 & 34.56 & 28.96 & 23.57 & 19.04 \\
\hline \multirow[t]{2}{*}{$\log ($ plant per firm $)$} & - & 0.030 & 0.019 & -0.015 & - & - \\
\hline & - & 15.55 & 13.14 & -4.63 & - & - \\
\hline \multirow[t]{2}{*}{ Plant age $(/ 100)$} & - & 0.323 & 0.366 & 0.346 & 0.351 & 0.319 \\
\hline & - & 8.63 & 13.12 & 10.53 & 8.36 & 8.16 \\
\hline Year fixed effects & $\mathrm{Y}$ & $\mathrm{Y}$ & $\mathrm{Y}$ & Y & & \\
\hline Industry fixed effects & & & $\mathrm{Y}$ & & & \\
\hline Industry-year fixed effects & & & & & & Y \\
\hline Firm fixed effects & & & & Y & & \\
\hline Firm-year fixed effects & & & & & Y & $\mathrm{Y}$ \\
\hline Observations & 154,000 & 154,000 & 154,000 & 154,000 & 154,000 & 154,000 \\
\hline $\mathrm{R}^{2}$ & $17.12 \%$ & $18.61 \%$ & $43.24 \%$ & $55.03 \%$ & $68.79 \%$ & $77.54 \%$ \\
\hline
\end{tabular}




\section{Table IV: Employer Concentration and Wages by Five-Year Time Period}

This table examines the basic effects of employer concentration in a local labor market on the wages of plants by five-year period from 1977 to 2009 . The dependent variable is the log of average wages per worker as defined in Table I. "HHI" and "log(employment)" are lagged by one year. Panels A and B present estimates using three- and four-digit SIC industries to compute HHI, $\log$ (employment), and $\log$ (plant per segment). The $t$-statistics based on standard errors adjusted for sample clustering at the county level are reported below the coefficient estimates. The numbers of observations are rounded to the nearest thousand to follow the Census Bureau's disclosure rules.

\section{Panel A: 3-digit SIC Industries}

\begin{tabular}{|c|c|c|c|c|c|c|}
\hline & (1) & (2) & (3) & (4) & (5) & (6) \\
\hline Subsample period: & 1977-1981 & 1982-1986 & 1987-1991 & 1992-1996 & 1997-2001 & $2002-2009$ \\
\hline Dep. Var.: & \multicolumn{6}{|c|}{ Log avg. wages } \\
\hline \multirow[t]{2}{*}{ HHI (SIC3-county-year) } & -0.018 & -0.012 & -0.015 & -0.031 & -0.039 & -0.029 \\
\hline & -2.75 & -1.78 & -1.95 & -4.59 & -5.31 & -4.18 \\
\hline \multirow[t]{2}{*}{ log(employment, SIC3-county-year) } & 0.029 & 0.031 & 0.030 & 0.025 & 0.021 & 0.023 \\
\hline & 24.35 & 23.09 & 20.38 & 16.45 & 10.98 & 11.75 \\
\hline \multirow[t]{2}{*}{$\log ($ labor productivity) } & 0.122 & 0.109 & 0.095 & 0.089 & 0.072 & 0.080 \\
\hline & 40.09 & 36.56 & 30.13 & 29.30 & 23.02 & 29.07 \\
\hline \multirow[t]{2}{*}{$\log ($ plant per segment) } & -0.009 & -0.014 & -0.024 & -0.028 & -0.020 & -0.025 \\
\hline & -3.87 & -5.32 & -10.36 & -11.70 & -8.37 & -10.21 \\
\hline \multirow[t]{2}{*}{ Plant age (/100) } & 1.681 & 0.971 & 0.591 & 0.514 & 0.473 & 0.267 \\
\hline & 16.24 & 16.31 & 12.85 & 18.37 & 18.71 & 14.48 \\
\hline Firm-year fixed effects & $\mathrm{Y}$ & $\mathrm{Y}$ & $\mathrm{Y}$ & $\mathrm{Y}$ & $\mathrm{Y}$ & $\mathrm{Y}$ \\
\hline Observations & 114,000 & 87,000 & 101,000 & 110,000 & 102,000 & 143,000 \\
\hline $\mathrm{R}^{2}$ & $66.02 \%$ & $65.65 \%$ & $62.84 \%$ & $62.30 \%$ & $56.36 \%$ & $60.87 \%$ \\
\hline
\end{tabular}


Panel B: 4-digit SIC Industries

\begin{tabular}{|c|c|c|c|c|c|c|}
\hline & (1) & (2) & (3) & (4) & (5) & (6) \\
\hline Subsample period: & 1977-1981 & $1982-1986$ & 1987-1991 & 1992-1996 & 1997-2001 & $2002-2009$ \\
\hline Dep. Var.: & \multicolumn{6}{|c|}{ Log avg. wages } \\
\hline \multirow[t]{2}{*}{ HHI (SIC4-county-year) } & -0.044 & -0.038 & -0.031 & -0.044 & -0.047 & -0.033 \\
\hline & -6.87 & -5.51 & -3.88 & -6.08 & -6.15 & -4.67 \\
\hline \multirow[t]{2}{*}{$\log ($ employment, SIC4-county-year) } & 0.022 & 0.022 & 0.024 & 0.018 & 0.017 & 0.021 \\
\hline & 21.97 & 18.87 & 18.10 & 13.78 & 10.05 & 11.81 \\
\hline \multirow[t]{2}{*}{$\log ($ labor productivity) } & 0.121 & 0.107 & 0.093 & 0.088 & 0.072 & 0.080 \\
\hline & 40.01 & 35.11 & 28.54 & 27.87 & 22.61 & 28.92 \\
\hline \multirow[t]{2}{*}{$\log ($ plant per segment $)$} & -0.008 & -0.012 & -0.023 & -0.024 & -0.017 & -0.021 \\
\hline & -3.63 & -5.34 & -10.42 & -10.67 & -7.42 & -8.40 \\
\hline \multirow[t]{2}{*}{ Plant age $(/ 100)$} & 1.728 & 1.001 & 0.603 & 0.538 & 0.476 & 0.264 \\
\hline & 16.59 & 16.44 & 12.78 & 19.09 & 18.71 & 14.32 \\
\hline Firm-year fixed effects & Y & Y & $\mathrm{Y}$ & Y & $\mathrm{Y}$ & $\mathrm{Y}$ \\
\hline Observations & 114,000 & 87,000 & 101,000 & 110,000 & 102,000 & 143,000 \\
\hline $\mathrm{R}^{2}$ & $65.70 \%$ & $65.24 \%$ & $62.51 \%$ & $61.91 \%$ & $56.12 \%$ & $60.70 \%$ \\
\hline
\end{tabular}




\section{Table V: Local Employer Concentration, Unions, and Wages}

This table examines the interactive effects of employer concentration in a local labor market and industry union coverage rates on the wages of plants. The dependent variable is the log of average wages per worker as defined in Table I. "HHI," "log(employment)," and "Union" are lagged by one year. Panels A and B present estimates using three- and four-digit SIC industries to compute HHI, $\log ($ employment), and log(plant per segment). The $t$-statistics based on standard errors adjusted for sample clustering at the county level are reported below the coefficient estimates. The numbers of observations are rounded to the nearest thousand to follow the Census Bureau's disclosure rules.

\section{Panel A: 3-digit SIC Industries}

\begin{tabular}{|c|c|c|c|c|c|c|}
\hline & (1) & (2) & (3) & (4) & (5) & (6) \\
\hline Dep. Var. & \multicolumn{6}{|c|}{ Log avg. wages } \\
\hline \multirow[t]{2}{*}{ HHI (SIC3-county-year) } & -0.135 & -0.153 & -0.070 & -0.094 & -0.087 & -0.079 \\
\hline & -8.05 & -9.40 & -6.41 & -11.62 & -10.39 & -9.86 \\
\hline \multirow[t]{2}{*}{ log(employment, SIC3-county-year) } & 0.039 & 0.036 & 0.036 & 0.025 & 0.025 & 0.026 \\
\hline & 17.68 & 15.92 & 21.86 & 25.31 & 25.09 & 27.63 \\
\hline \multirow[t]{2}{*}{$\log ($ labor productivity) } & 0.148 & 0.148 & 0.102 & 0.092 & 0.092 & 0.065 \\
\hline & 48.73 & 48.21 & 55.77 & 49.09 & 44.90 & 36.81 \\
\hline \multirow[t]{2}{*}{ Union } & 0.108 & 0.109 & 0.136 & 0.097 & 0.109 & 0.169 \\
\hline & 2.14 & 2.15 & 4.96 & 4.47 & 4.78 & 1.45 \\
\hline \multirow[t]{2}{*}{ HHI x Union } & 0.407 & 0.402 & 0.145 & 0.237 & 0.228 & 0.131 \\
\hline & 7.29 & 7.20 & 4.09 & 8.99 & 8.59 & 5.59 \\
\hline \multirow[t]{2}{*}{$\log ($ plant per segment $)$} & - & -0.044 & -0.015 & -0.018 & -0.020 & -0.008 \\
\hline & - & -19.97 & -10.82 & -11.98 & -11.98 & -5.14 \\
\hline \multirow[t]{2}{*}{$\log ($ plant per firm $)$} & - & 0.040 & 0.021 & -0.016 & - & - \\
\hline & - & 26.85 & 19.28 & -8.79 & - & - \\
\hline \multirow[t]{2}{*}{ Plant age $(/ 100)$} & - & 0.408 & 0.427 & 0.397 & 0.405 & 0.358 \\
\hline & - & 17.45 & 24.58 & 22.88 & 22.86 & 21.88 \\
\hline Year fixed effects & Y & $\mathrm{Y}$ & Y & Y & & \\
\hline Industry fixed effects & & & $\mathrm{Y}$ & & & \\
\hline Industry-year fixed effects & & & & & & $\mathrm{Y}$ \\
\hline Firm fixed effects & & & & $\mathrm{Y}$ & & \\
\hline Firm-year fixed effects & & & & & $\mathrm{Y}$ & $\mathrm{Y}$ \\
\hline Observations & 656,000 & 656,000 & 656,000 & 656,000 & 656,000 & 656,000 \\
\hline $\mathrm{R}^{2}$ & $21.89 \%$ & $23.98 \%$ & $43.98 \%$ & $55.37 \%$ & $62.88 \%$ & $67.20 \%$ \\
\hline
\end{tabular}


Panel B: 4-digit SIC Industries

\begin{tabular}{|c|c|c|c|c|c|c|}
\hline & (1) & $(2)$ & (3) & (4) & (5) & (6) \\
\hline Dep. Var. & \multicolumn{6}{|c|}{ Log avg. wages } \\
\hline \multirow[t]{2}{*}{ HHI (SIC4-county-year) } & -0.111 & -0.131 & -0.072 & -0.086 & -0.080 & -0.074 \\
\hline & -5.40 & -6.52 & -6.50 & -9.07 & -8.41 & -8.21 \\
\hline \multirow[t]{2}{*}{ log(employment, SIC4-county-year) } & 0.031 & 0.029 & 0.026 & 0.019 & 0.020 & 0.019 \\
\hline & $\mathbf{1 7 . 2 3}$ & 15.75 & 28.03 & 23.29 & 22.86 & 28.41 \\
\hline \multirow[t]{2}{*}{$\log ($ labor productivity) } & 0.145 & 0.144 & 0.090 & 0.091 & 0.091 & 0.060 \\
\hline & 44.23 & 44.66 & 53.28 & 46.90 & 43.04 & 34.98 \\
\hline \multirow[t]{2}{*}{ Union } & 0.160 & 0.162 & 0.145 & 0.116 & 0.127 & - \\
\hline & 2.52 & 2.58 & 4.67 & 4.36 & 4.71 & - \\
\hline \multirow[t]{2}{*}{$\mathrm{HHI} \times$ Union } & 0.253 & 0.251 & 0.078 & 0.156 & 0.151 & 0.084 \\
\hline & 3.84 & 3.84 & 2.10 & 5.25 & 5.18 & 3.16 \\
\hline \multirow[t]{2}{*}{$\log ($ plant per segment $)$} & - & -0.038 & -0.013 & -0.017 & -0.019 & -0.007 \\
\hline & - & -19.74 & -11.16 & -12.08 & -12.02 & -5.01 \\
\hline \multirow[t]{2}{*}{$\log ($ plant per firm $)$} & - & 0.033 & 0.018 & -0.018 & - & - \\
\hline & - & 25.00 & 17.99 & -10.75 & - & - \\
\hline \multirow[t]{2}{*}{ Plant age $(/ 100)$} & - & 0.405 & 0.431 & 0.406 & 0.414 & 0.373 \\
\hline & - & 16.87 & 26.44 & 23.32 & 23.18 & 23.24 \\
\hline Year fixed effects & $\mathrm{Y}$ & $\mathrm{Y}$ & $\mathrm{Y}$ & $\mathrm{Y}$ & & \\
\hline Industry fixed effects & & & $\mathrm{Y}$ & & & \\
\hline Industry-year fixed effects & & & & & & Y \\
\hline Firm fixed effects & & & & $\mathrm{Y}$ & & \\
\hline Firm-year fixed effects & & & & & $\mathrm{Y}$ & $\mathrm{Y}$ \\
\hline Observations & 656,000 & 656,000 & 656,000 & 656,000 & 656,000 & 656,000 \\
\hline $\mathrm{R}^{2}$ & $20.60 \%$ & $22.44 \%$ & $48.41 \%$ & $54.96 \%$ & $62.50 \%$ & $67.99 \%$ \\
\hline
\end{tabular}




\section{Table VI: Employer Concentration and Sensitivities of Wage Changes to Productivity Changes}

This table examines how employer concentration shapes sensitivities of changes in production worker wages to changes in labor productivity. The dependent variable is the log change in average wages per production worker as defined in Table I. "HHI" is lagged by one year. Panels A and B present estimates using three- and four-digit SIC industries to compute HHI and $\log$ (plant per segment). $t$-statistics based on standard errors adjusted for sample clustering at the county level are reported below the coefficient estimates. The numbers of observations are rounded to the nearest thousand to follow the Census Bureau's disclosure rules.

\section{Panel A: 3-digit SIC Industries}

(1)

Dep. Var.

\begin{tabular}{|c|c|c|c|c|c|c|}
\hline \multirow{2}{*}{$\mathrm{HHI}$} & \multicolumn{6}{|c|}{$\Delta$ Log avg. production worker wages } \\
\hline & 0.004 & 0.004 & 0.005 & 0.004 & 0.004 & 0.005 \\
\hline \multirow{3}{*}{$\Delta \log ($ labor productivity) } & 7.55 & 8.05 & 8.77 & 7.42 & 7.32 & 7.58 \\
\hline & 0.152 & 0.152 & 0.152 & 0.151 & 0.146 & 0.146 \\
\hline & 35.54 & 35.56 & 35.53 & 35.35 & 31.85 & 31.83 \\
\hline \multirow[t]{2}{*}{ HHI $\times \Delta \log ($ labor productivity $)$} & -0.036 & -0.036 & -0.036 & -0.036 & -0.035 & -0.035 \\
\hline & -6.10 & -6.11 & -6.11 & -6.00 & -5.62 & -5.63 \\
\hline \multirow[t]{2}{*}{$\log ($ plant per segment $)$} & - & -0.001 & -0.001 & 0.000 & -0.001 & 0.000 \\
\hline & - & -5.06 & -2.97 & -1.50 & -1.80 & -1.20 \\
\hline \multirow[t]{2}{*}{$\log ($ plant per firm $)$} & - & 0.000 & 0.000 & 0.001 & - & - \\
\hline & - & 2.48 & 2.20 & 2.37 & - & - \\
\hline \multirow[t]{2}{*}{ Plant age $(/ 100)$} & - & -0.041 & -0.041 & -0.039 & -0.037 & -0.036 \\
\hline & - & -11.47 & -11.47 & $-\mathbf{1 0 . 5 5}$ & -9.34 & -9.00 \\
\hline Year fixed effects & $\mathrm{Y}$ & $\mathrm{Y}$ & $\mathrm{Y}$ & $\mathrm{Y}$ & & \\
\hline Industry fixed effects & & & $\mathrm{Y}$ & & & \\
\hline Industry-year fixed effects & & & & & & $\mathrm{Y}$ \\
\hline Firm fixed effects & & & & $\mathrm{Y}$ & & \\
\hline Firm-year fixed effects & & & & & $\mathrm{Y}$ & $\mathrm{Y}$ \\
\hline Observations & 656,000 & 656,000 & 656,000 & 656,000 & 656,000 & 656,000 \\
\hline $\mathrm{R}^{2}$ & $5.70 \%$ & $5.75 \%$ & $5.77 \%$ & $5.81 \%$ & $8.38 \%$ & $27.77 \%$ \\
\hline
\end{tabular}


Panel B: 4-digit SIC Industries

\begin{tabular}{|c|c|c|c|c|c|c|}
\hline & $(1)$ & $(2)$ & (3) & (4) & $(5)$ & (6) \\
\hline Dep. Var. & \multicolumn{6}{|c|}{$\Delta$ Log avg. production worker wages } \\
\hline \multirow[t]{2}{*}{$\mathrm{HHI}$} & 0.005 & 0.005 & 0.006 & 0.004 & 0.005 & 0.005 \\
\hline & 9.07 & 9.30 & 8.89 & 7.99 & 7.25 & 7.38 \\
\hline \multirow[t]{2}{*}{$\Delta \log$ (labor productivity) } & 0.157 & 0.157 & 0.156 & 0.156 & 0.151 & 0.151 \\
\hline & 28.94 & 28.97 & 28.93 & 29.26 & 26.63 & 26.65 \\
\hline \multirow[t]{2}{*}{$\mathrm{HHI} \times \Delta \log ($ labor productivity $)$} & -0.036 & -0.036 & -0.035 & -0.036 & -0.036 & -0.036 \\
\hline & -5.34 & -5.34 & -5.32 & -5.51 & -5.22 & -5.21 \\
\hline \multirow[t]{2}{*}{$\log ($ plant per segment $)$} & - & -0.001 & 0.000 & -0.001 & -0.001 & 0.000 \\
\hline & - & -5.88 & -1.31 & -2.23 & -2.23 & -0.60 \\
\hline \multirow[t]{2}{*}{$\log ($ plant per firm $)$} & - & 0.000 & 0.000 & 0.001 & - & - \\
\hline & - & 2.57 & 1.98 & 2.53 & - & - \\
\hline \multirow[t]{2}{*}{ Plant age $(/ 100)$} & - & -0.040 & -0.042 & -0.038 & -0.037 & -0.037 \\
\hline & - & -11.45 & -11.70 & -10.49 & -9.29 & -9.08 \\
\hline Year fixed effects & $\mathrm{Y}$ & $\mathrm{Y}$ & $\mathrm{Y}$ & $\mathrm{Y}$ & & \\
\hline Industry fixed effects & & & $\mathrm{Y}$ & & & \\
\hline Industry-year fixed effects & & & & & & $\mathrm{Y}$ \\
\hline Firm fixed effects & & & & $\mathrm{Y}$ & & \\
\hline Firm-year fixed effects & & & & & $\mathrm{Y}$ & $\mathrm{Y}$ \\
\hline Observations & 656,000 & 656,000 & 656,000 & 656,000 & 656,000 & 656,000 \\
\hline $\mathrm{R}^{2}$ & $5.75 \%$ & $5.77 \%$ & $5.85 \%$ & $8.38 \%$ & $27.77 \%$ & $27.81 \%$ \\
\hline
\end{tabular}




\section{Table VII: Nonlinear Effect of Local Employer Concentration on Wages}

This table examines nonlinear effects of employer concentration in a local labor market on the wages of plants. The dependent variable is the log of average wages per worker as defined in Table I. "HHI," "log(employment)," and "Union" are lagged by one year. HHI = 1 is an indicator variable equal to one if the HHI employer concentration measure is equal to one, and zero otherwise. Panels A and B present estimates using three- and four-digit SIC industries to compute HHI, $\log ($ employment), and $\log$ (plant per segment). $t$-statistics based on standard errors adjusted for sample clustering at the county level are reported below the coefficient estimates. The numbers of observations are rounded to the nearest thousand to follow the Census Bureau's disclosure rules.

\section{Panel A: 3-digit SIC Industries}

\begin{tabular}{|c|c|c|c|}
\hline & (1) & $(2)$ & (3) \\
\hline Dep. Var. & & Log avg. wages & \\
\hline \multirow[t]{2}{*}{$\mathrm{HHI}=1$} & -0.017 & -0.011 & -0.062 \\
\hline & -5.19 & -2.79 & -11.59 \\
\hline \multirow[t]{2}{*}{ HHI } & - & -0.013 & - \\
\hline & - & -1.99 & - \\
\hline \multirow[t]{2}{*}{$\log ($ employment $)$} & 0.028 & 0.027 & 0.027 \\
\hline & 26.12 & 26.47 & 24.63 \\
\hline \multirow[t]{2}{*}{$\log$ (labor productivity) } & 0.094 & 0.094 & 0.092 \\
\hline & 44.86 & 44.88 & 44.64 \\
\hline \multirow[t]{2}{*}{ Union } & - & - & 0.196 \\
\hline & - & - & 11.81 \\
\hline \multirow[t]{2}{*}{$(\mathrm{HHI}=1) \times$ Union } & - & - & 0.162 \\
\hline & - & - & 9.23 \\
\hline \multirow[t]{2}{*}{$\log ($ plant per segment $)$} & -0.020 & -0.020 & -0.020 \\
\hline & -11.59 & -11.55 & -12.00 \\
\hline \multirow[t]{2}{*}{ Plant age (/100) } & 0.409 & 0.412 & 0.399 \\
\hline & 23.29 & 23.25 & 22.73 \\
\hline Firm-year fixed effects & $\mathrm{Y}$ & $\mathrm{Y}$ & $\mathrm{Y}$ \\
\hline Observations & 656,000 & 656,000 & 656,000 \\
\hline $\mathrm{R}^{2}$ & $62.55 \%$ & $62.55 \%$ & $62.87 \%$ \\
\hline
\end{tabular}


Panel B: 4-digit SIC Industries

\begin{tabular}{lccc}
\hline \hline & $(1)$ & $(2)$ & $(3)$ \\
\hline HHI $=1$ & \multicolumn{3}{c}{ Log avg. wages } \\
& -0.031 & -0.029 & -0.058 \\
HHI & $-\mathbf{9 . 7 4}$ & $-\mathbf{7 . 4 3}$ & $-\mathbf{1 0 . 9 4}$ \\
& - & -0.006 & - \\
$\log ($ employment) & - & $-\mathbf{0 . 7 8}$ & - \\
& 0.021 & 0.021 & 0.020 \\
$\log ($ labor productivity) & $\mathbf{2 2 . 3 4}$ & $\mathbf{2 3 . 1 5}$ & $\mathbf{2 0 . 2 4}$ \\
& 0.093 & 0.093 & 0.091 \\
Union & $\mathbf{4 3 . 2 7}$ & $\mathbf{4 3 . 2 3}$ & $\mathbf{4 2 . 8 5}$ \\
& - & - & 0.186 \\
(HHI =1) $\times$ Union & - & - & $\mathbf{1 0 . 0 8}$ \\
& - & - & 0.101 \\
$\log ($ plant per segment) & - & - & $\mathbf{6 . 0 8}$ \\
& -0.018 & -0.018 & -0.020 \\
Plant age (/100) & $-\mathbf{1 1 . 3 5}$ & $-\mathbf{1 1 . 3 4}$ & $\mathbf{- 1 2 . 1 9}$ \\
Firm-year fixed effects & 0.419 & 0.419 & 0.408 \\
Observations & $\mathbf{2 3 . 3 9}$ & $\mathbf{2 3 . 5}$ & $\mathbf{2 2 . 8 7}$ \\
$\mathrm{R}^{2}$ & $\mathrm{Y}$ & $\mathrm{Y}$ & $\mathrm{Y}$ \\
\hline \hline
\end{tabular}




\section{Table VIII: Local Employer Concentration and Wages Controlling for National Concentration}

This table examines the effects of employer concentration in a local labor market on the wages of plants, including an additional control for employer concentration at the national level. The dependent variable is the log of average wages per worker as defined in Table I. "HHI" and "log(employment)" are lagged by one year. Panels A and B present estimates using three- and four-digit SIC industries to compute HHI, log(employment), and log(plant per segment). Local-level HHI is the Herfindahl-Hirschman Index of firm employment calculated at the industry-county-year level, while National HHI is the HerfindahlHirschman Index calculated at the industry-year level. $t$-statistics based on standard errors adjusted for sample clustering at the county level are reported below the coefficient estimates. The numbers of observations are rounded to the nearest thousand to follow the Census Bureau's disclosure rules.

\section{Panel A: 3-digit SIC Industries}

\begin{tabular}{|c|c|c|c|c|c|}
\hline & (1) & (2) & (3) & (4) & $(5)$ \\
\hline Dep. Var. & & & Log avg. wages & & \\
\hline \multirow[t]{2}{*}{ Local-level HHI } & -0.069 & -0.088 & -0.037 & -0.047 & -0.043 \\
\hline & -7.88 & -10.40 & -5.27 & -9.39 & -7.90 \\
\hline \multirow[t]{2}{*}{ National HHI } & 1.556 & 1.527 & -0.055 & 0.940 & 0.995 \\
\hline & 24.68 & 24.44 & -0.91 & 19.58 & $\mathbf{1 7 . 5 7}$ \\
\hline \multirow[t]{2}{*}{$\log$ (employment, SIC3-county-year) } & 0.036 & 0.033 & 0.036 & 0.024 & 0.025 \\
\hline & 16.55 & 14.82 & 21.68 & 24.21 & 23.88 \\
\hline \multirow{2}{*}{$\log ($ labor productivity) } & 0.151 & 0.150 & 0.102 & 0.093 & 0.092 \\
\hline & 46.58 & 45.89 & 55.75 & 48.31 & 43.93 \\
\hline \multirow[t]{2}{*}{$\log ($ plant per segment $)$} & - & -0.043 & -0.015 & -0.019 & -0.021 \\
\hline & - & -19.43 & -10.61 & -11.89 & -11.94 \\
\hline \multirow[t]{2}{*}{$\log ($ plant per firm $)$} & - & 0.040 & 0.021 & -0.016 & - \\
\hline & - & 26.20 & 19.32 & -8.69 & - \\
\hline \multirow[t]{2}{*}{ Plant age $(/ 100)$} & - & 0.413 & 0.425 & 0.400 & 0.408 \\
\hline & - & 17.03 & 24.32 & 22.72 & 22.83 \\
\hline Year fixed effects & $\mathrm{Y}$ & $\mathrm{Y}$ & $\mathrm{Y}$ & $\mathrm{Y}$ & \\
\hline Industry fixed effects & & & $\mathrm{Y}$ & & \\
\hline \multicolumn{6}{|l|}{ Industry-year fixed effects } \\
\hline Firm fixed effects & & & & $\mathrm{Y}$ & \\
\hline Firm-year fixed effects & & & & & $\mathrm{Y}$ \\
\hline Observations & 656,000 & 656,000 & 656,000 & 656,000 & 656,000 \\
\hline $\mathrm{R}^{2}$ & $21.88 \%$ & $23.94 \%$ & $43.90 \%$ & $55.34 \%$ & $62.88 \%$ \\
\hline
\end{tabular}


Panel B: 4-digit SIC Industries

\begin{tabular}{|c|c|c|c|c|c|}
\hline & (1) & (2) & (3) & (4) & (5) \\
\hline Dep. Var. & & & Log avg. wages & & \\
\hline \multirow[t]{2}{*}{ Local-level HHI } & -0.092 & -0.110 & -0.054 & -0.060 & -0.055 \\
\hline & -8.78 & -10.75 & -8.20 & -11.28 & -9.67 \\
\hline \multirow[t]{2}{*}{ National HHI } & 0.994 & 0.963 & -0.157 & 0.442 & 0.464 \\
\hline & 30.62 & 29.74 & -4.65 & 16.06 & 14.88 \\
\hline \multirow[t]{2}{*}{$\log$ (employment, SIC4-county-year) } & 0.028 & 0.026 & 0.026 & 0.019 & 0.020 \\
\hline & 16.87 & 15.47 & 27.82 & 23.86 & 23.33 \\
\hline \multirow[t]{2}{*}{$\log$ (labor productivity) } & 0.146 & 0.147 & 0.090 & 0.092 & 0.092 \\
\hline & 42.29 & 43.25 & 53.21 & 46.63 & 42.43 \\
\hline \multirow[t]{2}{*}{$\log ($ plant per segment $)$} & - & -0.038 & -0.013 & -0.016 & -0.019 \\
\hline & - & -19.59 & -11.00 & -11.74 & -11.79 \\
\hline \multirow[t]{2}{*}{$\log ($ plant per firm $)$} & - & 0.031 & 0.018 & -0.018 & - \\
\hline & - & 23.83 & 18.13 & -11.18 & - \\
\hline \multirow[t]{2}{*}{ Plant age $(/ 100)$} & - & 0.393 & 0.431 & 0.405 & 0.412 \\
\hline & - & 16.06 & 26.43 & 22.96 & 22.91 \\
\hline Year fixed effects & $\mathrm{Y}$ & $\mathrm{Y}$ & $\mathrm{Y}$ & $\mathrm{Y}$ & \\
\hline Industry fixed effects & & & Y & & \\
\hline \multicolumn{6}{|l|}{ Industry-year fixed effects } \\
\hline Firm fixed effects & & & & Y & \\
\hline Firm-year fixed effects & & & & & $\mathrm{Y}$ \\
\hline Observations & 656,000 & 656,000 & 656,000 & 656,000 & 656,000 \\
\hline $\mathrm{R}^{2}$ & $21.07 \%$ & $22.78 \%$ & $48.38 \%$ & $54.88 \%$ & $62.44 \%$ \\
\hline
\end{tabular}




\section{Table IX: Local Employer Concentration and Wages Controlling for Labor Value-Added}

This table examines the effects of employer concentration in a local labor market on the wages of plants including an additional control for labor productivityvalued added (total value of shipments + net increase in inventories of finished goods and works in progress - material and energy costs) scaled by labor hours. The dependent variable is the log of average wages per worker as defined in Table I. "HHI" and "log(employment)" are lagged by one year. Panels A and B present estimates using three- and four-digit SIC industries to compute HHI, log(employment), and log(plant per segment). The $t$-statistics based on standard errors adjusted for sample clustering at the county level are reported below the coefficient estimates. The numbers of observations are rounded to the nearest thousand to follow the Census Bureau's disclosure rules.

\section{Panel A: 3-digit SIC Industries}

\begin{tabular}{|c|c|c|c|c|c|c|}
\hline & (1) & (2) & (3) & (4) & (5) & (6) \\
\hline Dep. Var. & \multicolumn{6}{|c|}{ Log avg. wages } \\
\hline \multirow{2}{*}{ HHI (SIC3-county-year) } & -0.025 & -0.044 & -0.038 & -0.028 & -0.023 & -0.049 \\
\hline & -2.91 & -5.45 & -5.37 & -5.61 & -4.29 & -9.47 \\
\hline \multirow[t]{2}{*}{$\log ($ employment, SIC3-county-year) } & 0.041 & 0.038 & 0.036 & 0.027 & 0.027 & 0.026 \\
\hline & 17.95 & 16.16 & 21.30 & 26.99 & 26.74 & 27.10 \\
\hline \multirow[t]{2}{*}{$\log$ (labor productivity) } & 0.144 & 0.144 & 0.098 & 0.097 & 0.096 & 0.061 \\
\hline & 43.59 & 43.70 & 48.87 & 45.73 & 41.63 & 30.01 \\
\hline \multirow[t]{2}{*}{$\log ($ labor VA) } & 0.016 & 0.015 & 0.005 & -0.002 & -0.001 & 0.004 \\
\hline & 9.86 & 9.14 & 5.26 & -2.65 & -1.49 & 5.35 \\
\hline \multirow[t]{2}{*}{$\log ($ plant per segment $)$} & - & -0.041 & -0.014 & -0.017 & -0.020 & -0.007 \\
\hline & - & -19.01 & -10.57 & -11.32 & -11.46 & -5.03 \\
\hline \multirow[t]{2}{*}{$\log ($ plant per firm $)$} & - & 0.041 & 0.021 & -0.016 & - & - \\
\hline & - & 26.65 & 19.27 & -8.91 & - & - \\
\hline \multirow[t]{2}{*}{ Plant age $(/ 100)$} & - & 0.424 & 0.424 & 0.405 & 0.413 & 0.357 \\
\hline & - & 17.64 & 24.23 & 23.25 & 23.34 & 21.93 \\
\hline Year fixed effects & $\mathrm{Y}$ & $\mathrm{Y}$ & $\mathrm{Y}$ & Y & & \\
\hline Industry fixed effects & & & $\mathrm{Y}$ & & & \\
\hline Industry-year fixed effects & & & & & & Y \\
\hline Firm fixed effects & & & & $\mathrm{Y}$ & & \\
\hline Firm-year fixed effects & & & & & $\mathrm{Y}$ & $\mathrm{Y}$ \\
\hline Observations & 656,000 & 656,000 & 656,000 & 656,000 & 656,000 & 656,000 \\
\hline $\mathrm{R}^{2}$ & $20.67 \%$ & $22.74 \%$ & $43.92 \%$ & $55.00 \%$ & $62.55 \%$ & $67.19 \%$ \\
\hline
\end{tabular}


Panel B: 4-digit SIC Industries

\begin{tabular}{|c|c|c|c|c|c|c|}
\hline & (1) & (2) & (3) & (4) & (5) & (6) \\
\hline Dep. Var. & \multicolumn{6}{|c|}{ Log avg. wages } \\
\hline \multirow[t]{2}{*}{ HHI (SIC4-county-year) } & -0.042 & -0.063 & -0.055 & -0.043 & -0.038 & -0.055 \\
\hline & -4.28 & -6.58 & -8.36 & -8.33 & -6.90 & -10.82 \\
\hline \multirow[t]{2}{*}{$\log$ (employment, SIC4-county-year) } & 0.033 & 0.030 & 0.026 & 0.020 & 0.021 & 0.019 \\
\hline & 17.77 & 16.24 & 27.42 & 25.21 & 24.77 & 28.22 \\
\hline \multirow[t]{2}{*}{$\log$ (labor productivity) } & 0.139 & 0.138 & 0.082 & 0.095 & 0.094 & 0.054 \\
\hline & 38.94 & 39.93 & 39.99 & 43.71 & 39.83 & 26.51 \\
\hline \multirow[t]{2}{*}{$\log ($ labor VA) } & 0.019 & 0.018 & 0.009 & -0.001 & -0.001 & 0.006 \\
\hline & 11.08 & 10.57 & 10.04 & -1.59 & -0.60 & 7.93 \\
\hline \multirow[t]{2}{*}{$\log ($ plant per segment $)$} & - & -0.035 & -0.013 & -0.015 & -0.017 & -0.007 \\
\hline & - & -18.14 & -11.14 & $-\mathbf{1 1 . 0 7}$ & -11.16 & -5.01 \\
\hline \multirow[t]{2}{*}{$\log ($ plant per firm $)$} & - & 0.034 & 0.018 & -0.019 & - & - \\
\hline & - & 24.89 & 18.09 & -11.17 & - & - \\
\hline \multirow[t]{2}{*}{ Plant age (/100) } & - & 0.425 & 0.428 & 0.414 & 0.421 & 0.372 \\
\hline & - & 17.36 & 26.19 & 23.69 & 23.62 & 23.30 \\
\hline Year fixed effects & $\mathrm{Y}$ & Y & $\mathrm{Y}$ & Y & & \\
\hline Industry fixed effects & & & $\mathrm{Y}$ & & & \\
\hline Industry-year fixed effects & & & & & & Y \\
\hline Firm fixed effects & & & & Y & & \\
\hline Firm-year fixed effects & & & & & $\mathrm{Y}$ & Y \\
\hline Observations & 656,000 & 656,000 & 656,000 & 656,000 & 656,000 & 656,000 \\
\hline $\mathrm{R}^{2}$ & $19.73 \%$ & $21.53 \%$ & $48.41 \%$ & $54.67 \%$ & $62.23 \%$ & $69.24 \%$ \\
\hline
\end{tabular}




\section{Table X: China Import Penetration, Local Employer Concentration, and Wages}

This table examines the effects of employer concentration in a local labor market on wages controlling for the effect of import penetration from China on wages. The dependent variable is the log of average wages per worker as defined in Table I. "HHI" and "log(employment)" are lagged by one year. "China exposure" is defined as total value of import from China to the U.S. scaled by total value of shipments at the industry by year level. Panels A and B present estimates using three- and four-digit SIC industries to compute the HHI, China exposure, log(employment), and log(plant per segment). The $t$-statistics based on standard errors adjusted for sample clustering at the county level are reported below the coefficient estimates. The numbers of observations are rounded to the nearest thousands to follow the Census Bureau's disclosure rules.

\begin{tabular}{|c|c|c|c|c|c|}
\hline & (1) & (2) & (3) & (4) & $(5)$ \\
\hline Dep. Var. & & & Log avg. wages & & \\
\hline \multirow[t]{2}{*}{ HHI (SIC3-county-year) } & -0.041 & -0.065 & -0.035 & -0.032 & -0.043 \\
\hline & -4.36 & -7.25 & -6.39 & -5.31 & -4.93 \\
\hline \multirow[t]{2}{*}{ China exposure (SIC3-year) } & -0.001 & -0.001 & -0.001 & -0.001 & -0.001 \\
\hline & -4.01 & -5.96 & -5.01 & -5.01 & -7.22 \\
\hline \multirow[t]{2}{*}{$\log ($ employment, SIC3-county-year) } & 0.039 & 0.035 & 0.023 & 0.024 & 0.033 \\
\hline & 14.29 & 12.14 & 17.81 & 17.03 & 15.63 \\
\hline \multirow[t]{2}{*}{$\log$ (labor productivity) } & 0.138 & 0.137 & 0.080 & 0.082 & 0.134 \\
\hline & 36.94 & 37.33 & 36.75 & 34.18 & 41.29 \\
\hline \multirow[t]{2}{*}{$\log ($ plant per segment $)$} & - & -0.051 & -0.023 & -0.025 & -0.048 \\
\hline & - & -24.25 & -13.63 & -13.28 & -23.96 \\
\hline \multirow[t]{2}{*}{$\log ($ plant per firm $)$} & - & 0.043 & -0.011 & - & 0.042 \\
\hline & - & 24.47 & -4.75 & - & 24.61 \\
\hline \multirow[t]{2}{*}{ Plant age $(/ 100)$} & - & 0.432 & 0.384 & 0.388 & 0.423 \\
\hline & - & 17.79 & 21.92 & 21.18 & 20.04 \\
\hline Year fixed effects & $\mathrm{Y}$ & $\mathrm{Y}$ & $\mathrm{Y}$ & & $\mathrm{Y}$ \\
\hline \multicolumn{6}{|l|}{ Industry fixed effects } \\
\hline Firm fixed effects & & & $\mathrm{Y}$ & & \\
\hline Firm-year fixed effects & & & & Y & \\
\hline County fixed effects & & & & & Y \\
\hline Observations & 346,000 & 346,000 & 346,000 & 346,000 & 346,000 \\
\hline $\mathrm{R}^{2}$ & $15.60 \%$ & $18.35 \%$ & $54.05 \%$ & $60.36 \%$ & $21.18 \%$ \\
\hline
\end{tabular}


Panel B: 4-digit SIC Industries

\begin{tabular}{|c|c|c|c|c|c|}
\hline & (1) & (2) & (3) & (4) & (5) \\
\hline Dep. Var. & & & Log avg. wages & & \\
\hline \multirow{2}{*}{ HHI (SIC4-county-year) } & -0.051 & -0.076 & -0.046 & -0.042 & -0.046 \\
\hline & -4.53 & -7.13 & -7.69 & -6.57 & -4.71 \\
\hline \multirow[t]{2}{*}{ China exposure (SIC4-year) } & -0.001 & -0.001 & -0.001 & -0.001 & -0.002 \\
\hline & -5.76 & -7.75 & -4.75 & -4.56 & -9.09 \\
\hline \multirow[t]{2}{*}{$\log ($ employment, SIC4-county-year) } & 0.031 & 0.027 & 0.018 & 0.019 & 0.027 \\
\hline & 13.88 & 11.78 & 16.45 & 15.59 & 15.26 \\
\hline \multirow[t]{2}{*}{$\log$ (labor productivity) } & 0.134 & 0.135 & 0.079 & 0.081 & 0.131 \\
\hline & 34.20 & 35.04 & 35.57 & 33.13 & 39.55 \\
\hline \multirow[t]{2}{*}{$\log ($ plant per segment $)$} & - & -0.044 & -0.020 & -0.022 & -0.041 \\
\hline & - & -22.12 & -12.28 & -11.96 & -21.86 \\
\hline \multirow[t]{2}{*}{$\log ($ plant per firm $)$} & - & 0.034 & -0.015 & - & 0.033 \\
\hline & - & 21.24 & -6.38 & - & 21.66 \\
\hline \multirow[t]{2}{*}{ Plant age $(/ 100)$} & - & 0.434 & 0.392 & 0.395 & 0.421 \\
\hline & - & 17.66 & 22.33 & 21.47 & 19.72 \\
\hline Year fixed effects & $\mathrm{Y}$ & $\mathrm{Y}$ & $\mathrm{Y}$ & & $\mathrm{Y}$ \\
\hline \multicolumn{6}{|l|}{ Industry fixed effects } \\
\hline Firm fixed effects & & & $\mathrm{Y}$ & & \\
\hline Firm-year fixed effects & & & & $\mathrm{Y}$ & \\
\hline County fixed effects & & & & & $\mathrm{Y}$ \\
\hline Observations & 346,000 & 346,000 & 346,000 & 346000 & 346,000 \\
\hline $\mathrm{R}^{2}$ & $14.65 \%$ & $17.09 \%$ & $53.73 \%$ & $60.04 \%$ & $20.31 \%$ \\
\hline
\end{tabular}




\section{Table XI: The Exposure to Chinese Imports and Local Employer Concentration}

This table examines how exposure to China import penetration affects local-level employer concentration. The table uses three-digit SIC industries to compute HHI, China exposure, $\log ($ employment), and $\log$ (plant per segment). The dependent variable is HHI as defined in Table I. $t$-statistics based on standard errors adjusted for sample clustering at the county level are reported below the coefficient estimates. The numbers of observations are rounded to the nearest thousand to follow the Census Bureau's disclosure rules.

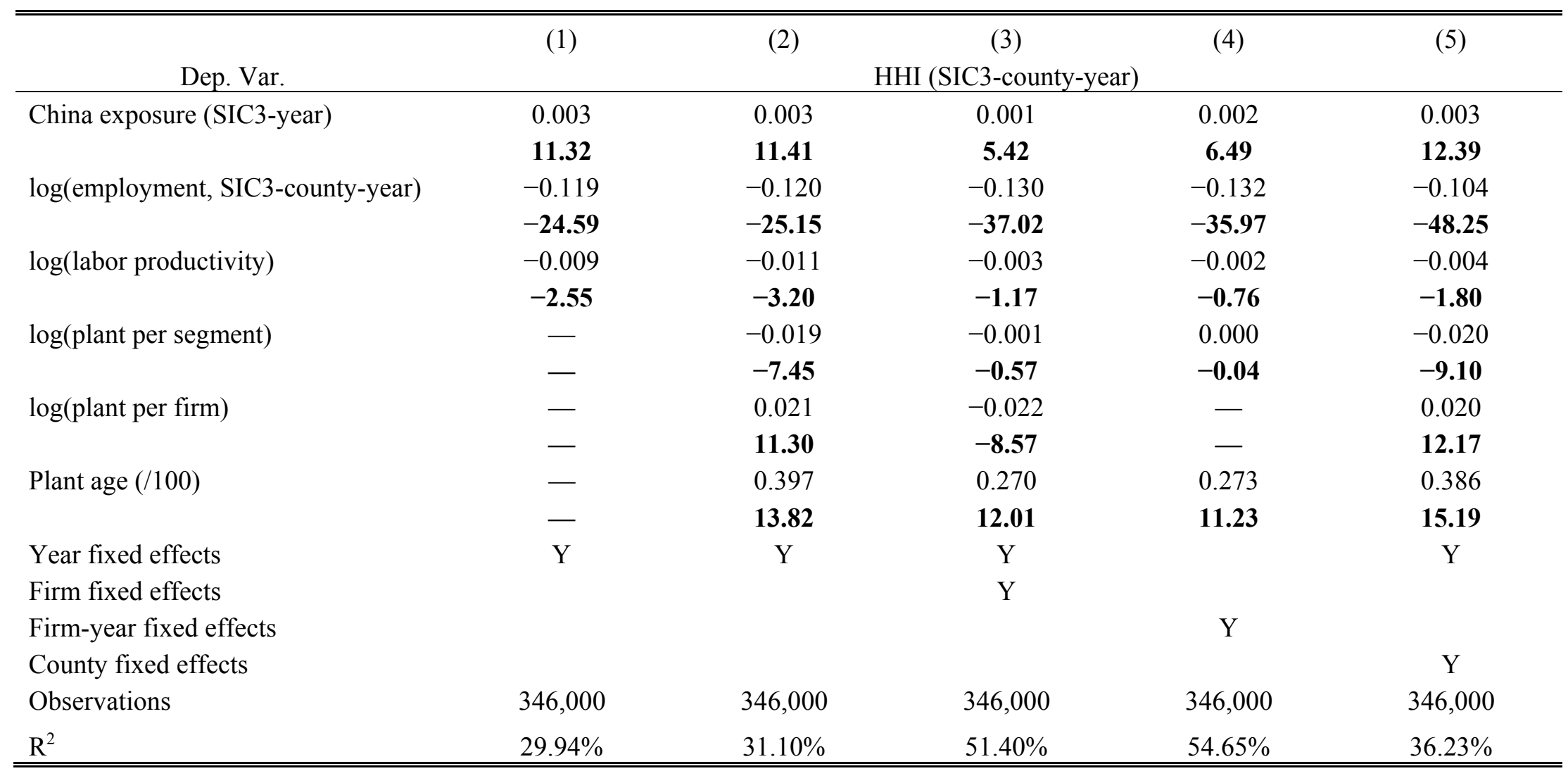

